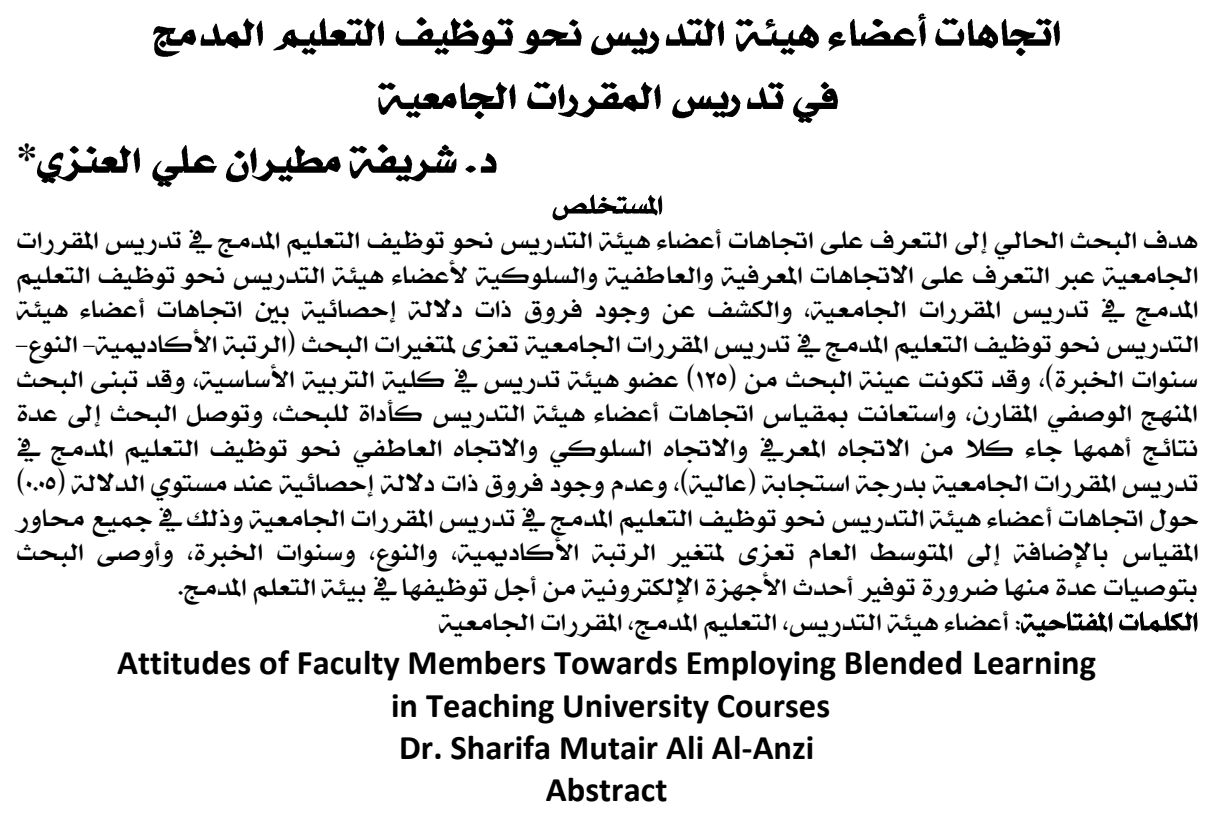

This research aimed to identify the attitudes of faculty members towards employing blended learning in teaching university courses by identifying the cognitive, emotional, and behavioral attitudes of faculty members towards employing blended learning in teaching university courses, and investigate the existence of statistically significant differences between the attitudes of faculty members towards employing blended learning in teaching university courses due to research variables (academic ranks - gender - years of experience). The research sample consisted of (125) faculty members in the College of Basic Education. The research adopted the comparative approach and used the faculty members' attitudes scale as the research tool. The research concluded many results including that the cognitive attitudes, the behavioral attitudes, and the emotional attitudes towards employing blended learning in teaching university courses came with a (high) response degree. Also, there were no statistically significant differences at the significance level (0.05) about the faculty members' attitudes towards employing blended learning in teaching university courses in all axes of the scale in addition to the overall mean due to the variable of academic rank, gender, and years of experience. The research reached several recommendations, including the need to provide the latest electronic devices in order to employ them in the blended learning environment.

Keywords: faculty members, blended learning, university courses 


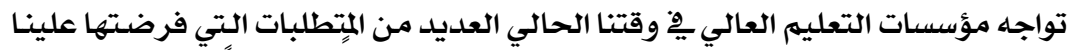

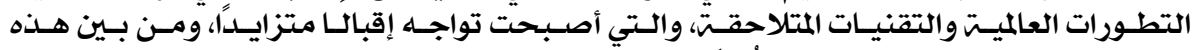

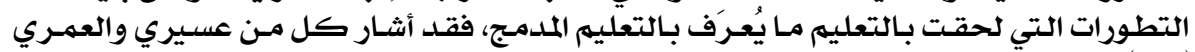

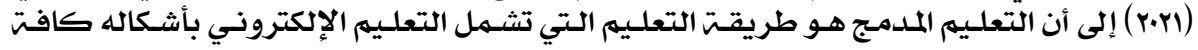

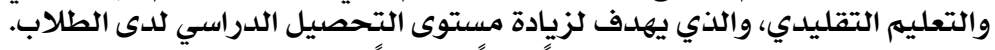

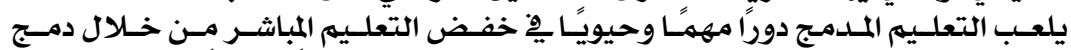

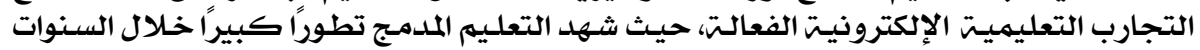

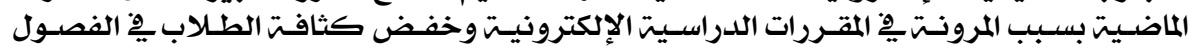

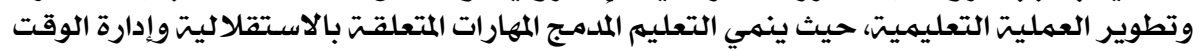

بشكل جيد والشعور بالر احت أثناء استخدام التكنولوجيا (Napier, Dekhane \& Smith, 2011).

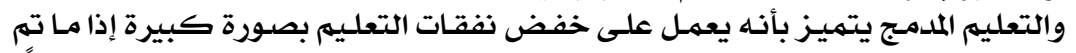

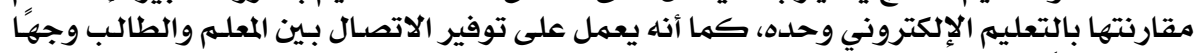

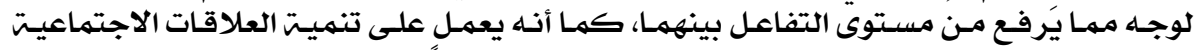

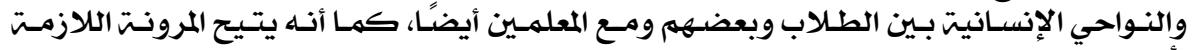

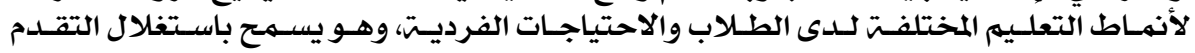

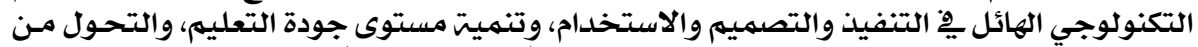

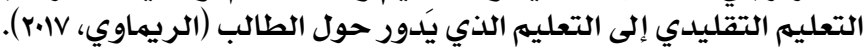

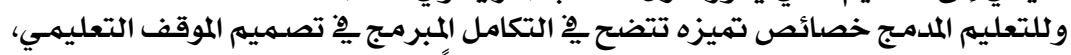

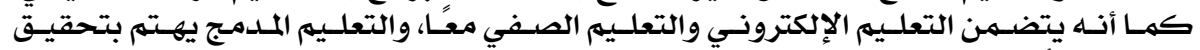

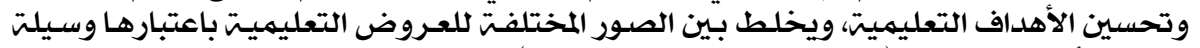

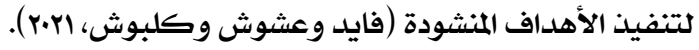

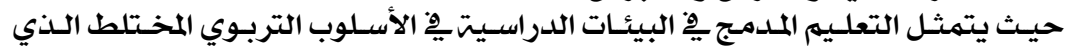

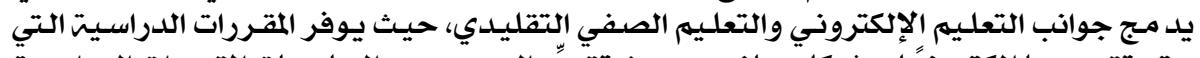

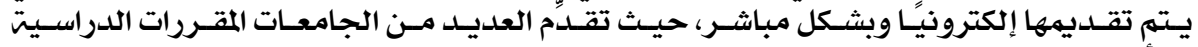

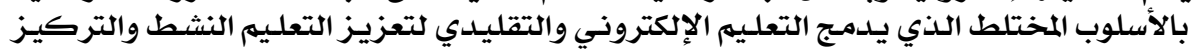
على الطلاب (Hamza-Lup \& White, 2015).

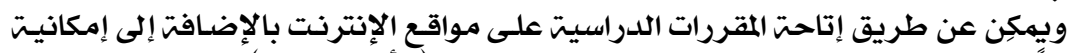

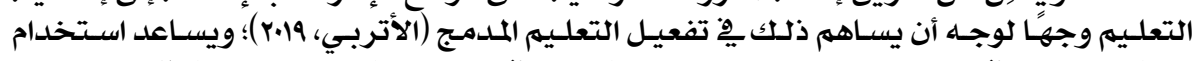

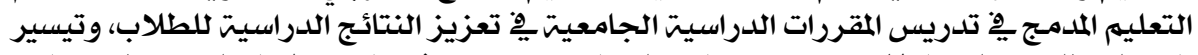

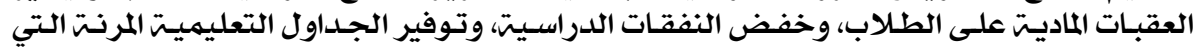
تتفق مع الظروف الشخصيت للطلاب (Hamza-Lup \& White, 2015).

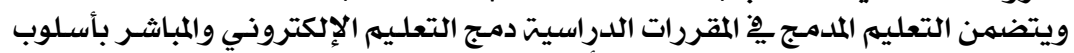

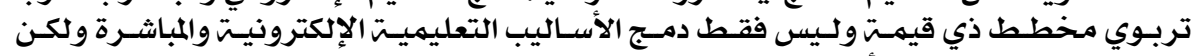

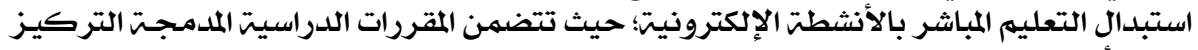

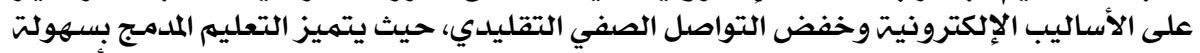

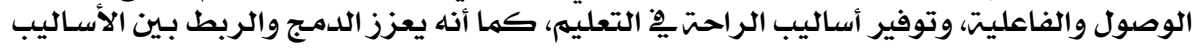

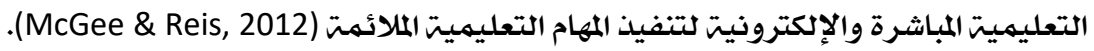

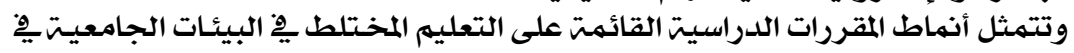

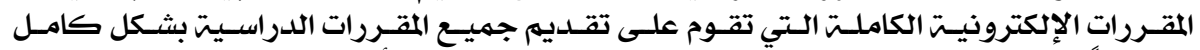

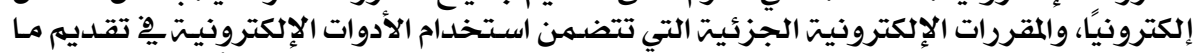

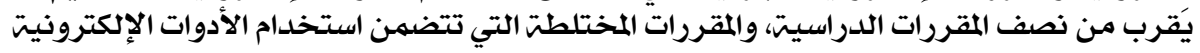

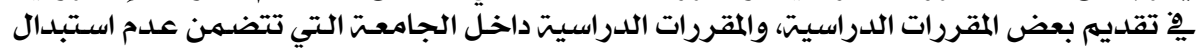
المقررات الدراسيت التقليديت بالمقررات الإلكترونيت (Hamza-Lup \& White, 2015). 


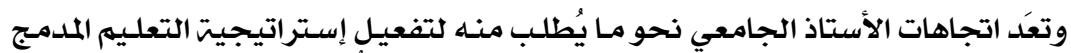

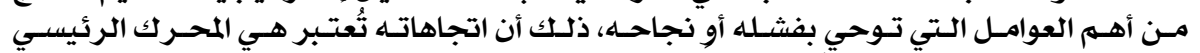

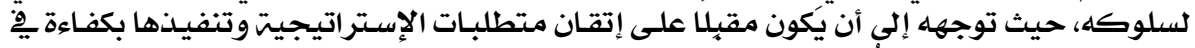

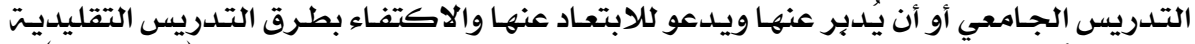

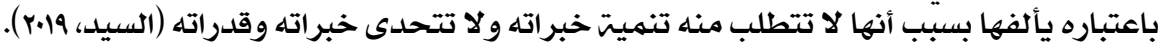

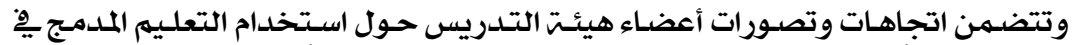

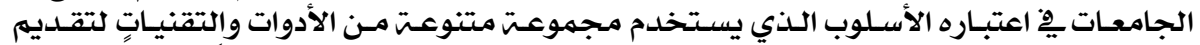

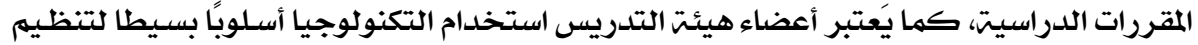

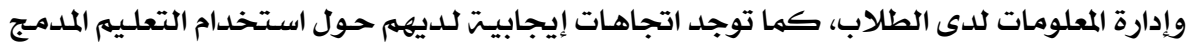

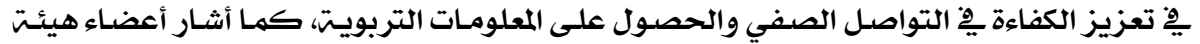

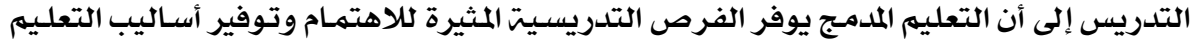

المتنوعت (Benson et al., 2011).

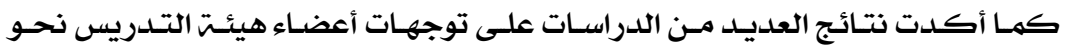

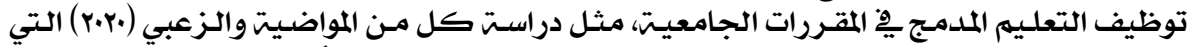

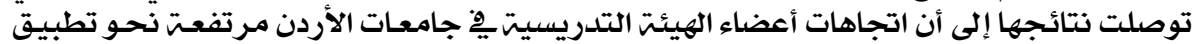

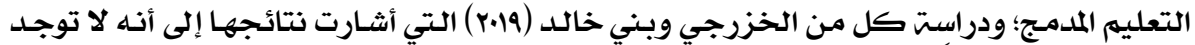

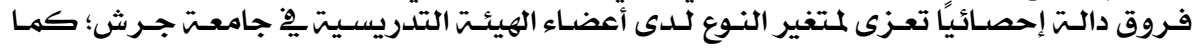

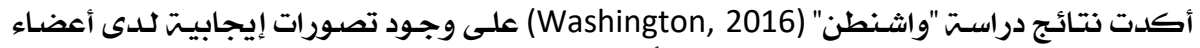

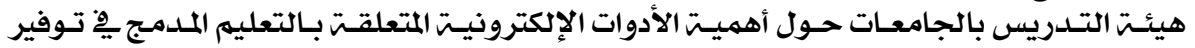

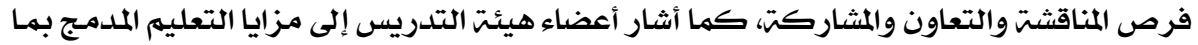

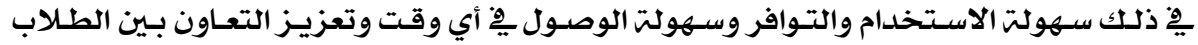
وأعضاء هيئت التدريس.

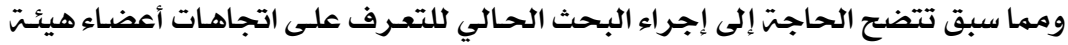

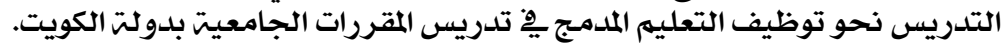

مشكلت البحث وتساؤلاته

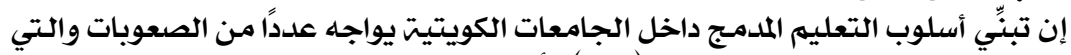

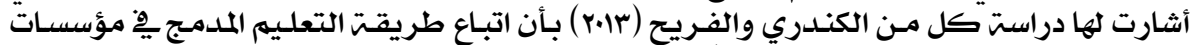

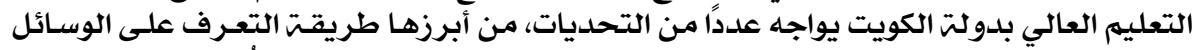

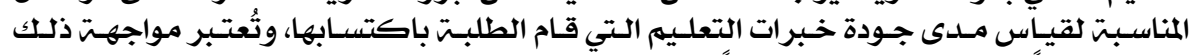

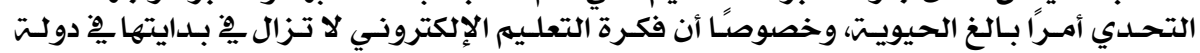
الكويت.

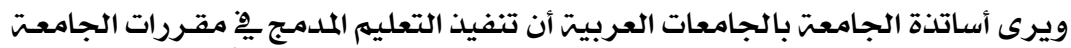

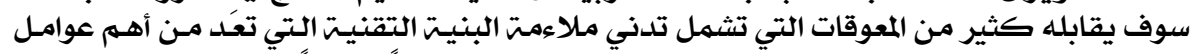

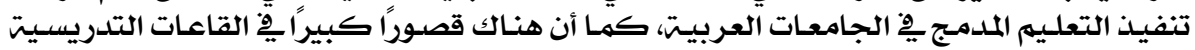

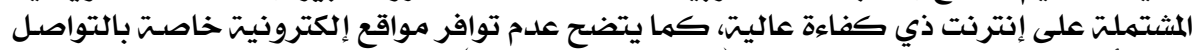

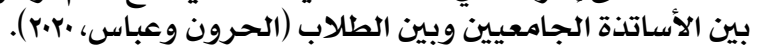

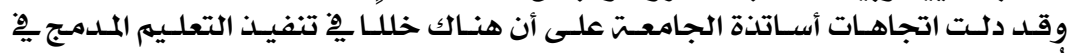

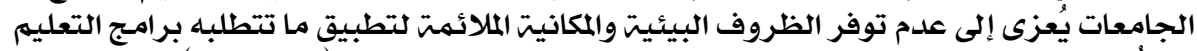

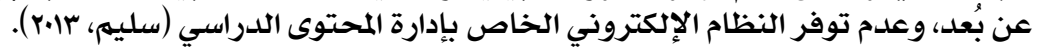

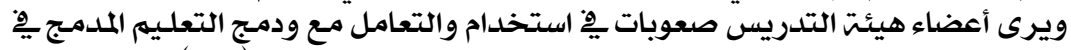

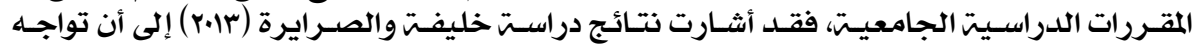

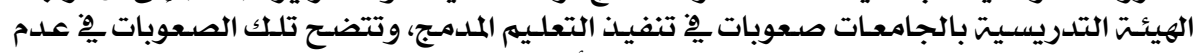

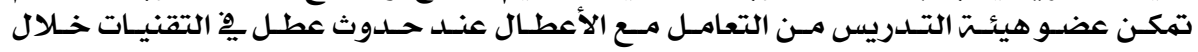

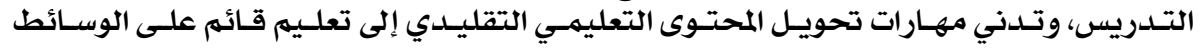




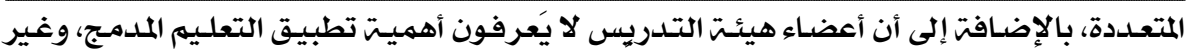

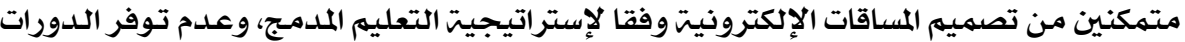

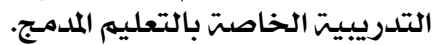

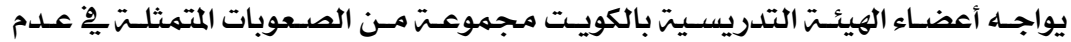

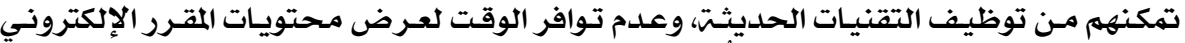

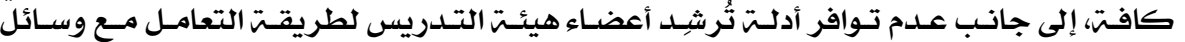

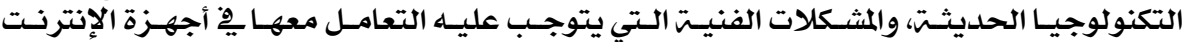

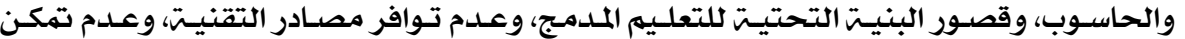

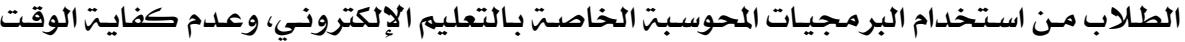

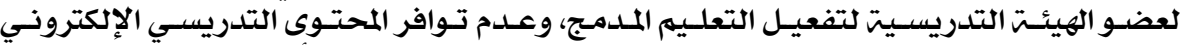

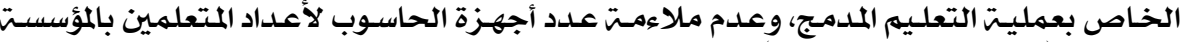

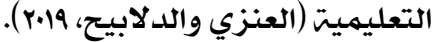

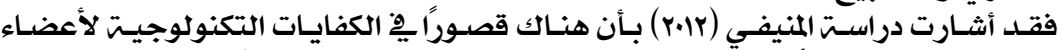

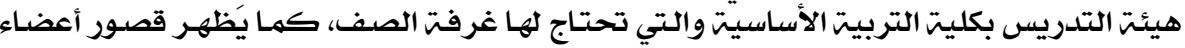

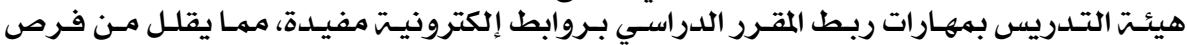

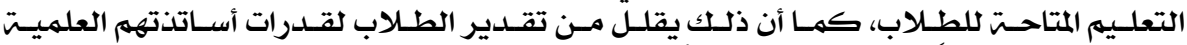

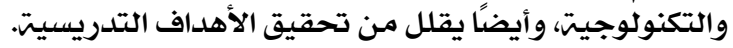

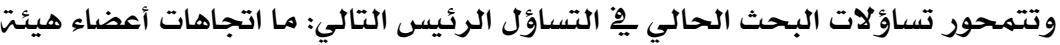

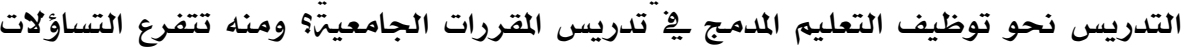

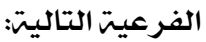

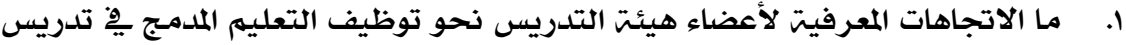
المقررات الجامعيت؟ الاتهيت

ما الاتجاهات العاطفيت لأعضاء هيئتة التدريس نحو توظيف التعليم المدمـج ِِّ تدريس

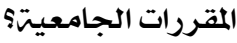

r. ما الاتجاهات السلوكيت لأعضاء هيئت التدريس نحو توظيف التعليه المدمـج يْ تدريس المقررات الجامعيتئ

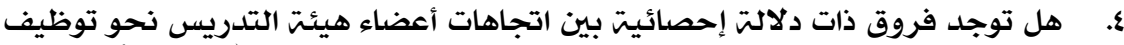

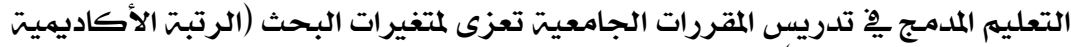

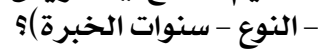

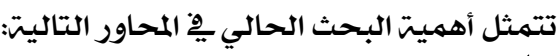
أهميـث البـحث الأهميت النظريتي:

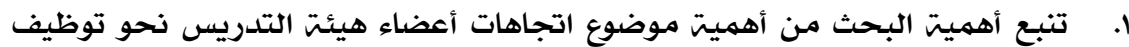

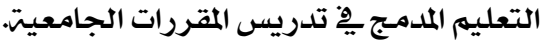

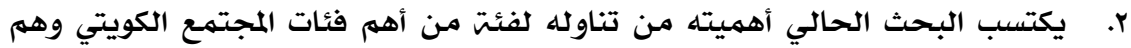

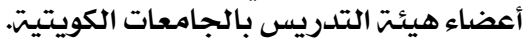

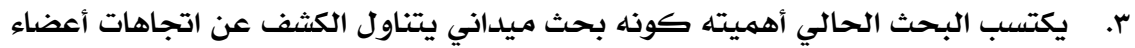

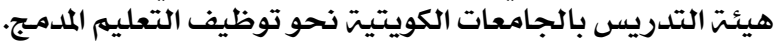

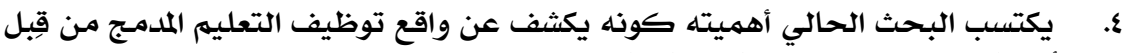

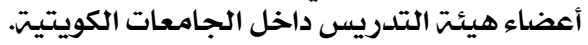


الأهميت التطبيقيت:

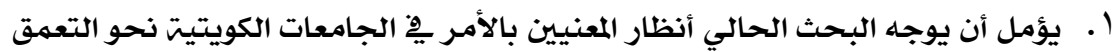

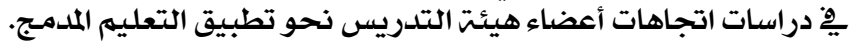

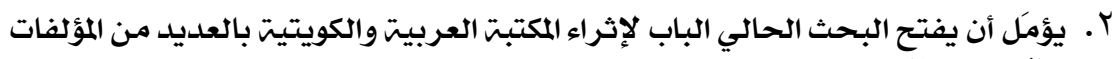
توفِ هذا المجال المهم.

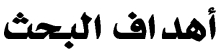

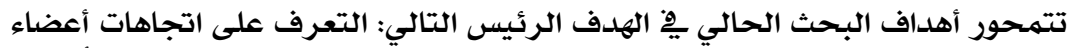

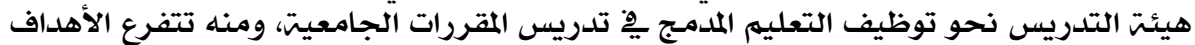

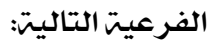

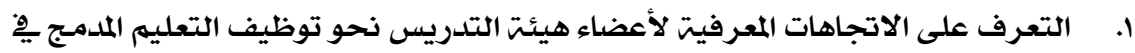
تدريس المقررات الجامعيت.

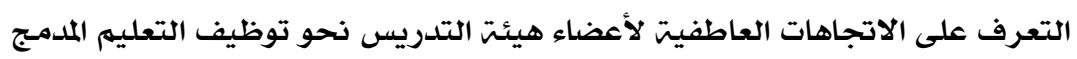
هِِ تدريس المقررات الجامعيت.

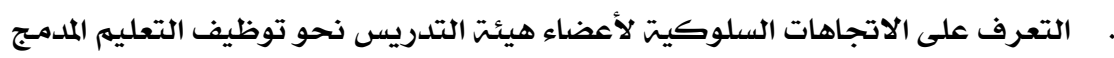

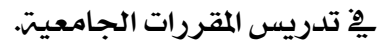

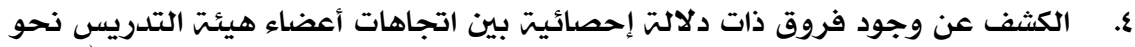

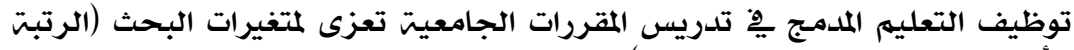
الأكاديميتة - النوع - سنوات الخبرة) حلد ود البحث الإد البحثي الأحلدود البشريتة: تتمثل الحدود البشريت فِ أعضاء هيئت التدريس فِ كليت التربيت الأساسيت.

$$
\text { • • الحدود المكانيت: تم التطبيق داخل جميع أقسام كليت التربيت الأساسيت. }
$$

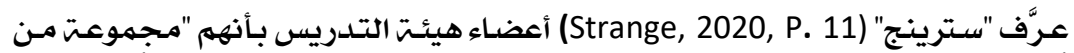

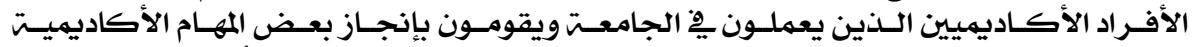

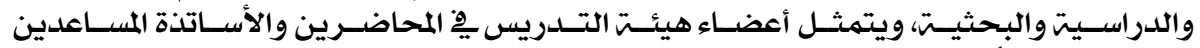
والمثاركين والأساتذة الجامعيين".

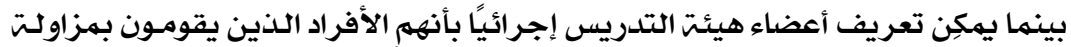

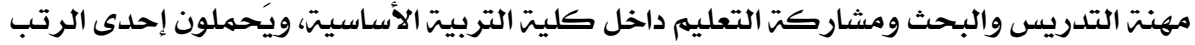
العلميت الخاصت بالجامعتض.

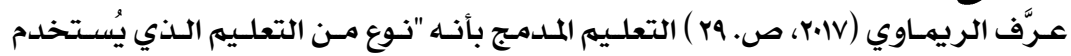

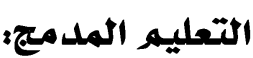

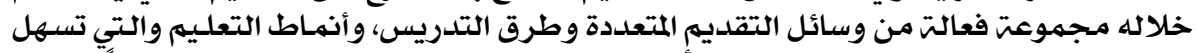

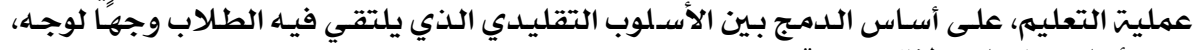
وبين أسلوب التعليم الإلكتروني". 


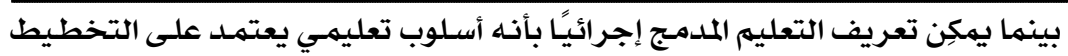

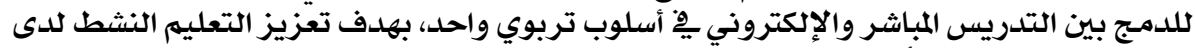

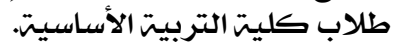
المقردات آجمامعينه

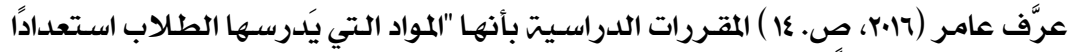

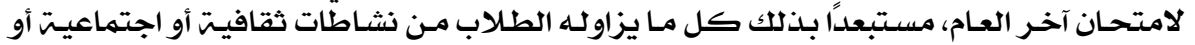

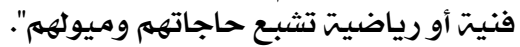

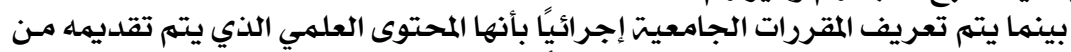
خلال أعضاء هيئت التدريس لطلاب كليت المقريت التربيت الأساسيتيا.

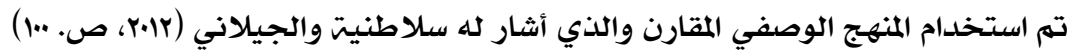
منهج البـحث

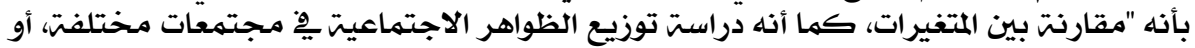

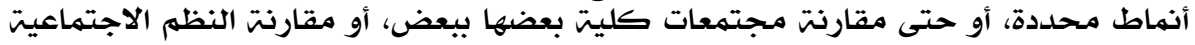

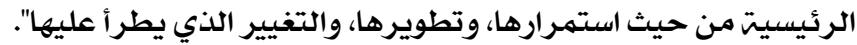

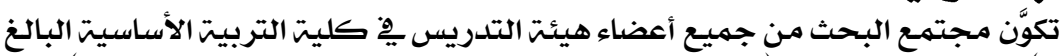

\section{مجتمع البحث ومينته}

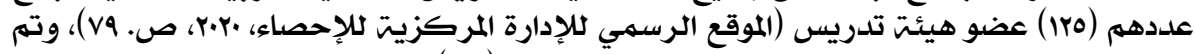

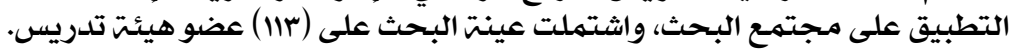

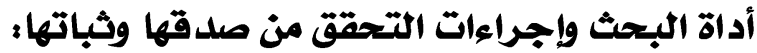

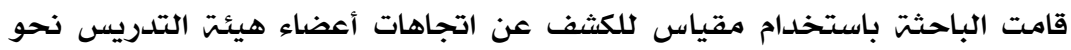

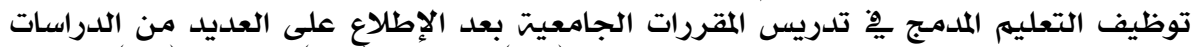

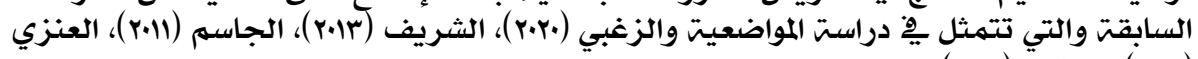

\section{وصف أداة البحث أبحث}

لقد احتوى المقياس يْ واة صورته النهائيت على جزئيسين رئيسين وهمها:

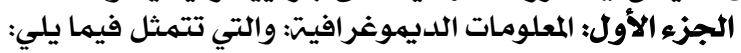

ا- الرتبت الأكاديميت: والتي تتمثل ِِّ (محاضر، أستاذ مساعد، أستاذ مشارك،

أستاذ).

$$
\text { r- النوع: والذي يتمثل يخ (ذكر، أنثى). }
$$

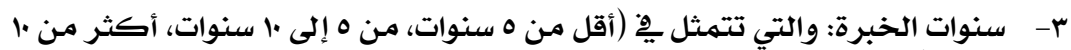

$$
\text { سنوات). }
$$

الجزء الثاني: ويحتوي على المقياس، ويتكون من (بr) عبارة موزعت على (r) محاور

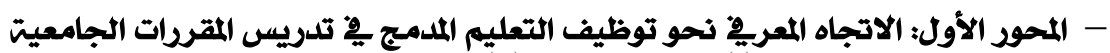

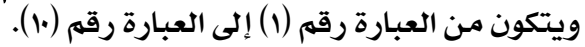

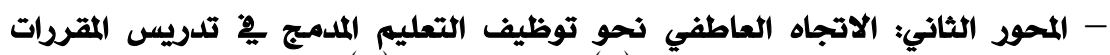

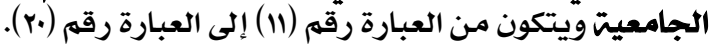

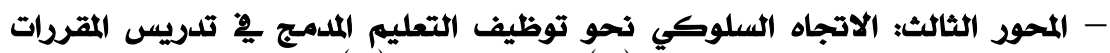

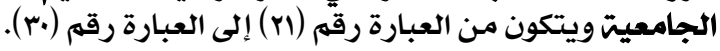




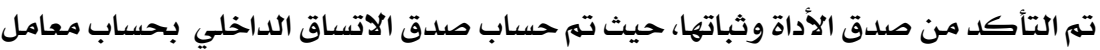
صلدق الأداة وثباتهاء

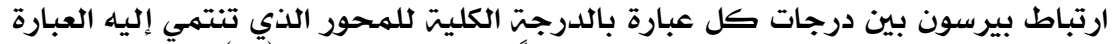

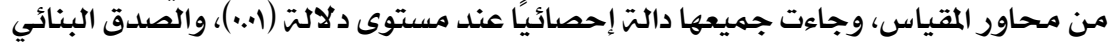

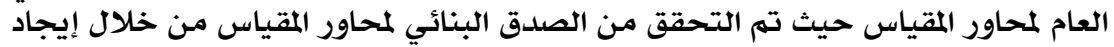

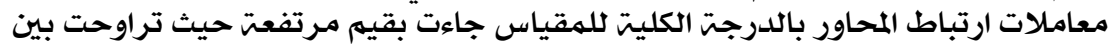

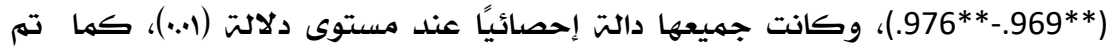

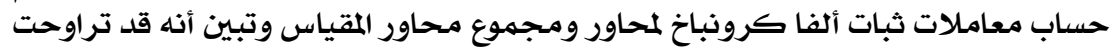

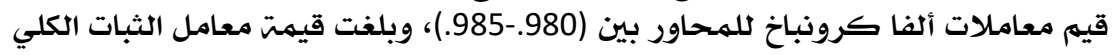

لمحاور المقياس (985.).

الأساليب الإحصائين

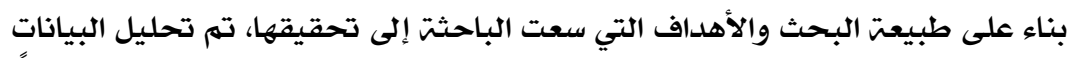

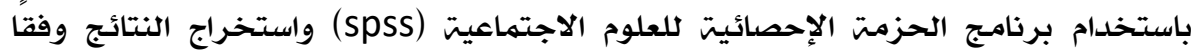

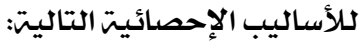

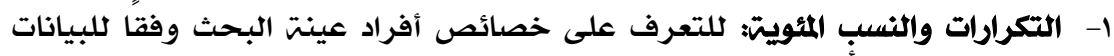

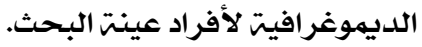

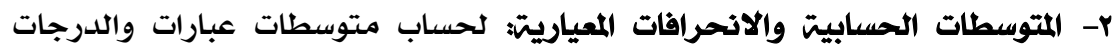
الكليت لمحاور المقياس.

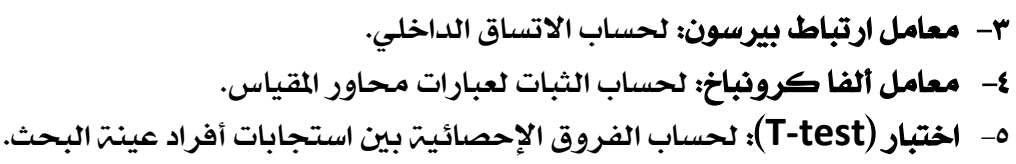

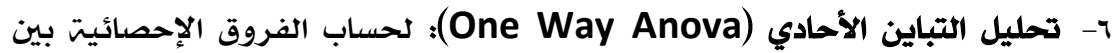
استجابات أفراد عينت البحثي الإدي V- معادلت المدى: وذلك لوصف المتوسط الحسابي للاستجابات على كل عبارة على النحو

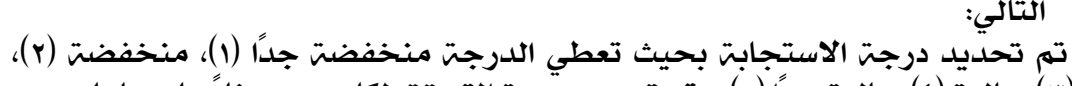

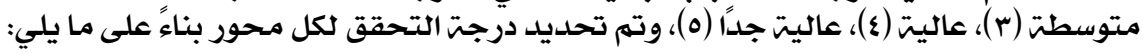

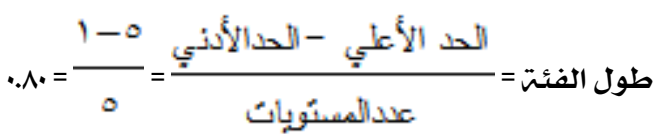

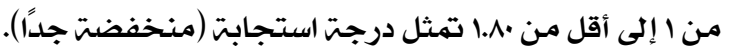

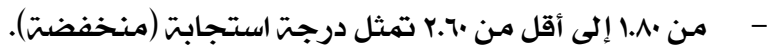

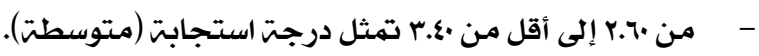

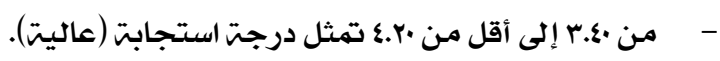

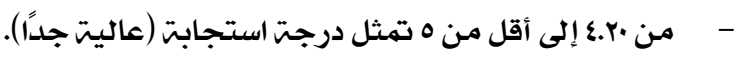




\section{عرض ومناقشت وتفنير أسئلتم البحث}

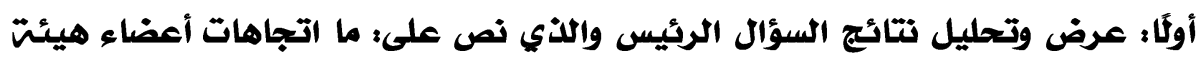

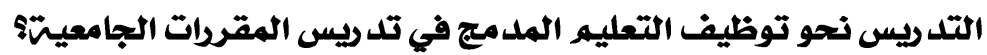

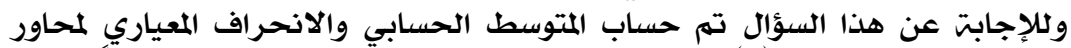

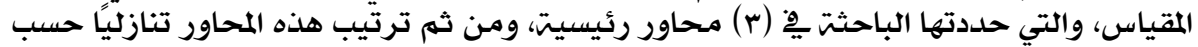

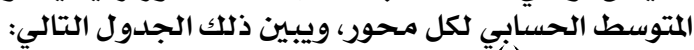

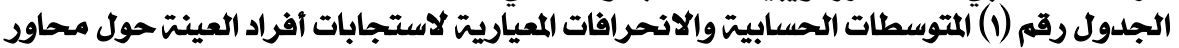

\begin{tabular}{|c|c|c|c|c|c|}
\hline \multicolumn{6}{|c|}{ المقياس } \\
\hline الاستججابت & الترتيب & الالمعياري & المستوسطي & المحاور & الرقم \\
\hline عاليت & 1 & .745 & 3.61 & 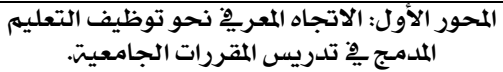 & 1 \\
\hline عاليت & r & .754 & 3.55 & 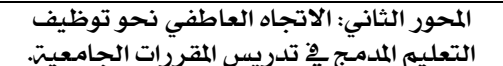 & $r$ \\
\hline عاليت & $r$ & .749 & 3.51 & 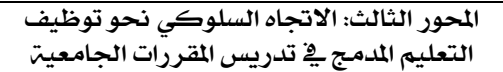 & $r$ \\
\hline \multicolumn{2}{|c|}{ عاليت } & .624 & 3.56 & \multicolumn{2}{|l|}{ المتوسط العام } \\
\hline
\end{tabular}

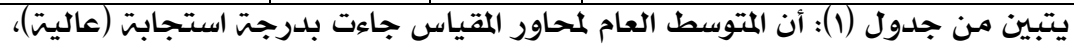

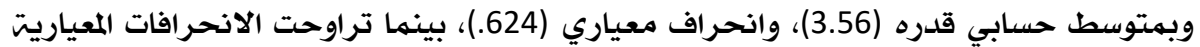

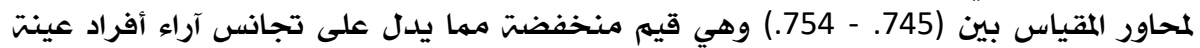
البحث نحو تللك المحاور بين (لمقاور.

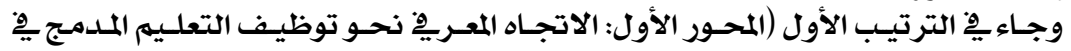

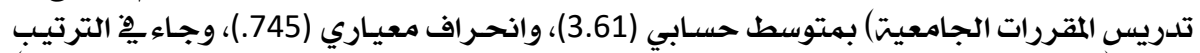

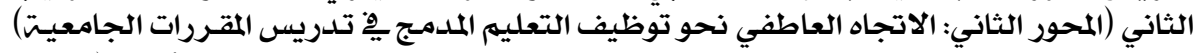

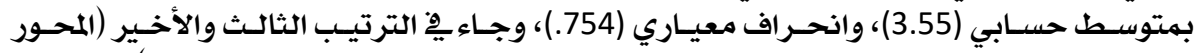

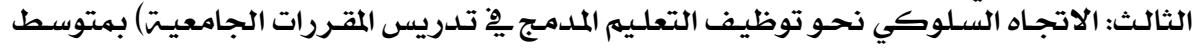

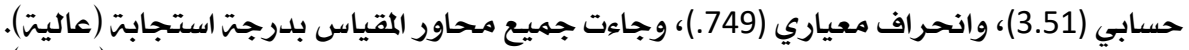

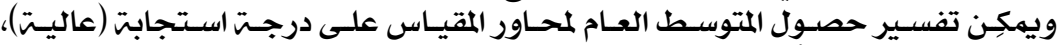

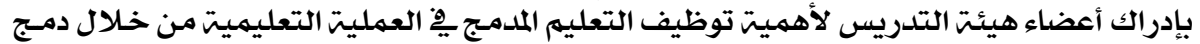

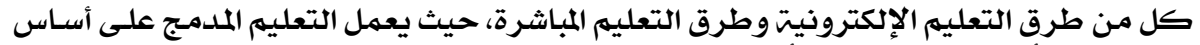

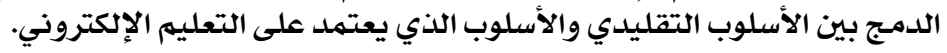

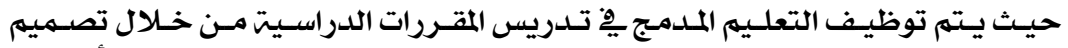

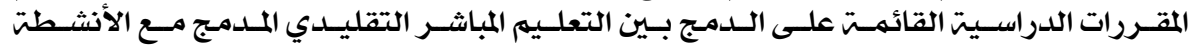

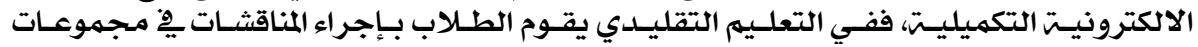

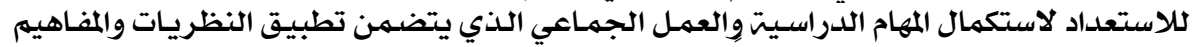

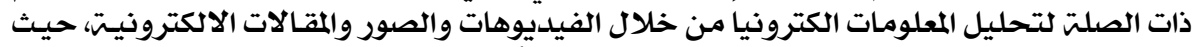

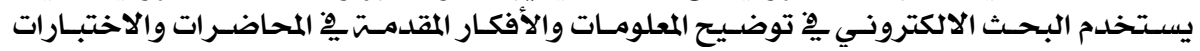

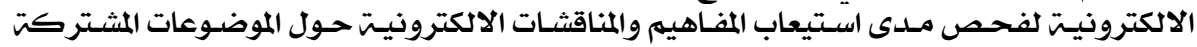

.(Ellis,Bliuc\&Han, 2021,P. 4)

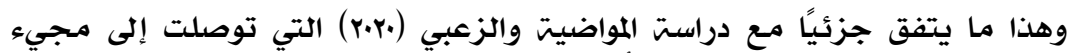

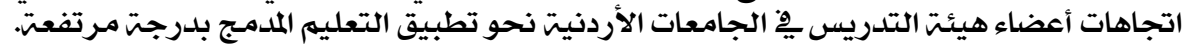


ثانيًا: عرض وتحليل نتائج السؤال الأول والذي نص على: ما الاتجاهات المعرفيت

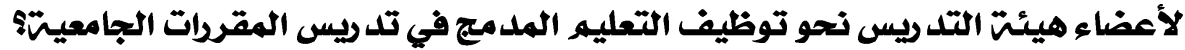

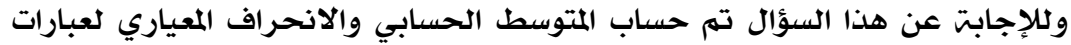

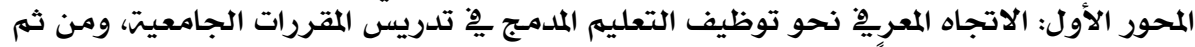

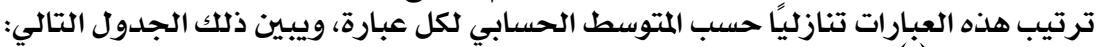

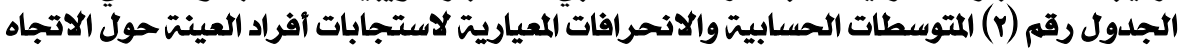

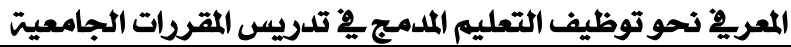

\begin{tabular}{|c|c|c|c|c|c|}
\hline الاستجابت & الترتيب & الالنحياري & المتوسابي & \multicolumn{2}{|l|}{ العبارة } \\
\hline عاليت & $r$ & 1.406 & 3.71 & 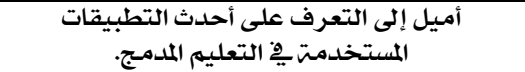 & 1 \\
\hline عاليت & $r$ & 1.425 & 3.71 & 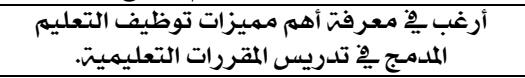 & $r$ \\
\hline عاليت & 0 & 1.304 & 3.63 & 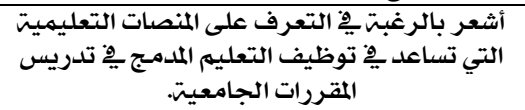 & $r$ \\
\hline عاليت & 7 & 1.286 & 3.59 & 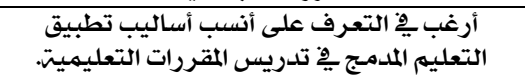 & $\varepsilon$ \\
\hline عاليت & $\wedge$ & 1.446 & 3.50 & 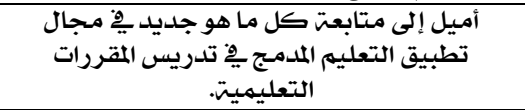 & 0 \\
\hline عاليت & $\varepsilon$ & 1.350 & 3.69 & 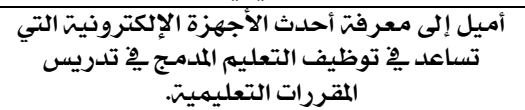 & 1 \\
\hline عاليت & 1 & 1.313 & 3.75 & 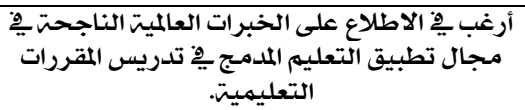 & $v$ \\
\hline عاليت & 9 & 1.364 & 3.49 & 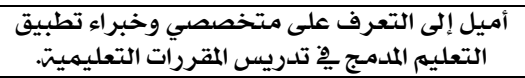 & $\wedge$ \\
\hline عاليت & $v$ & 1.487 & 3.57 & 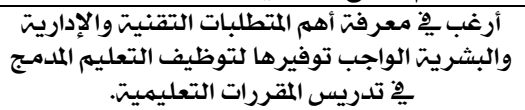 & 9 \\
\hline عاليت & 1. & 1.389 & 3.46 & 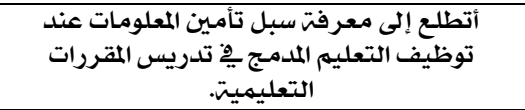 & 1. \\
\hline \multicolumn{2}{|c|}{ عاليت } & .745 & 3.61 & \multicolumn{2}{|l|}{ المتوسط العام } \\
\hline
\end{tabular}

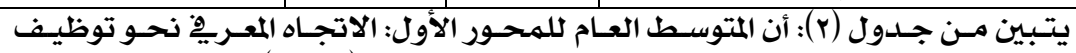

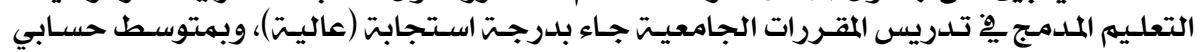

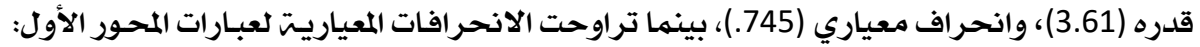

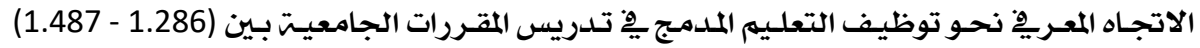

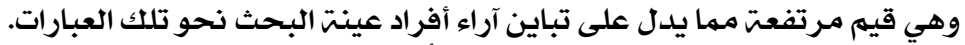

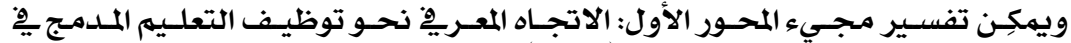

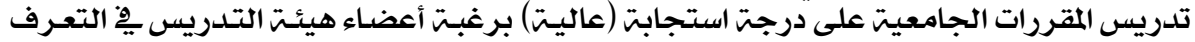

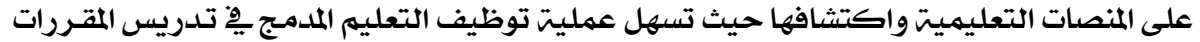

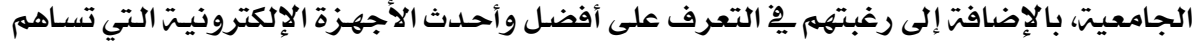

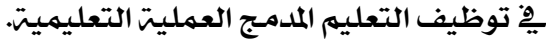




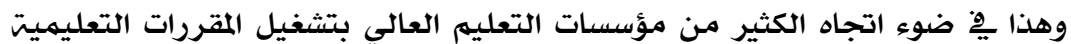

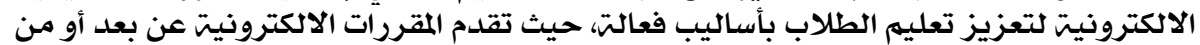

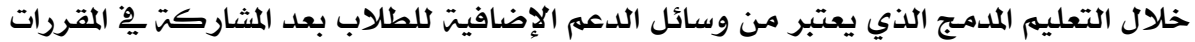

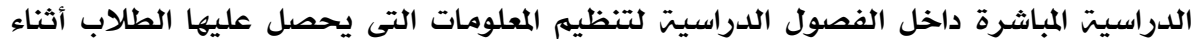

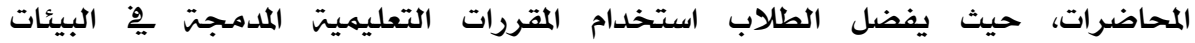
التعليميت(Klimova,Simonova\&Poulova, 2017, P. 2).

ثالثًاء عرض وتحليل نتائج السؤال الثاني والذي نص على: ما الاتجاهات العاطفيت

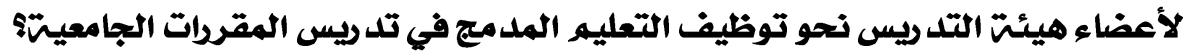

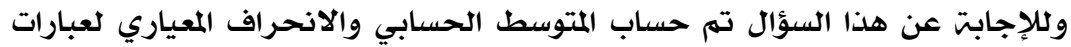

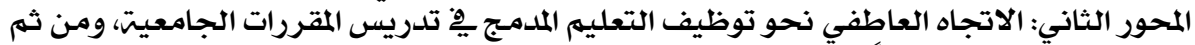

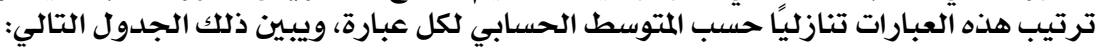

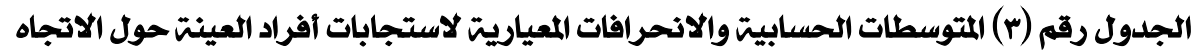

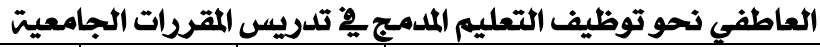

\begin{tabular}{|c|c|c|c|c|c|}
\hline الاستجابت & الترتيب & الانحياري & المتوسطابي & العبارة & \\
\hline عاليت & r & 1.354 & 3.71 & أشعر أن التعليه المدمئج يوفر الوقت والجهــ لعضو & 11 \\
\hline عاليت & $r$ & 1.285 & 3.61 & أشعر بالسعادة لمراعاة التعليم المدمـج للفروق المتعلمين. & ir \\
\hline عاليت & 1 & 1.351 & 3.82 & 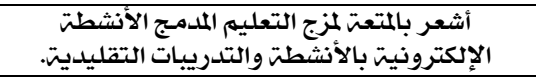 & ir \\
\hline عاليت & $v$ & 1.203 & 3.48 & أعتقد أن التعليم المدمجاجِيرفع مستوى تحصيل & $\mathbb{1}$ \\
\hline عاليت & $\varepsilon$ & 1.279 & 3.60 & أعتقد أن التعليم المدمرج قد خفف من أعبائي & 10 \\
\hline عاليت & $\wedge$ & 1.259 & 3.42 & أرى أن التعليم المدمعلجمينمي روح التعاون بين & 17 \\
\hline عاليت & 0 & 1.280 & 3.58 & 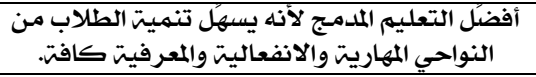 & IV \\
\hline عاليت & 7 & 1.350 & 3.50 & 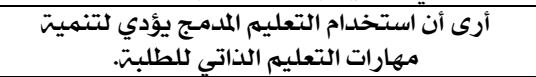 & 11 \\
\hline عاليت & 1. & 1.243 & 3.40 & 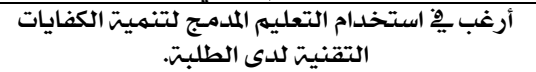 & 19 \\
\hline عاليت & 9 & 1.266 & 3.42 & 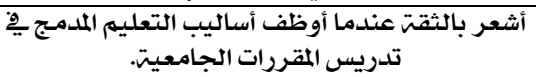 & $r$. \\
\hline \multicolumn{2}{|c|}{ عاليت } & .754 & 3.55 & \multicolumn{2}{|l|}{ المتوسط العام } \\
\hline
\end{tabular}

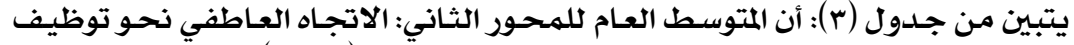

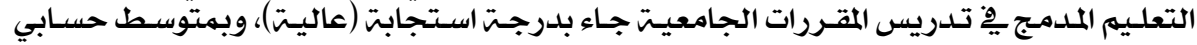

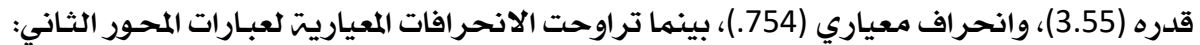

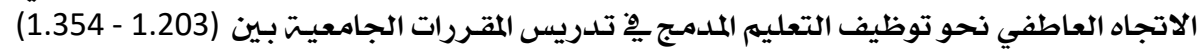

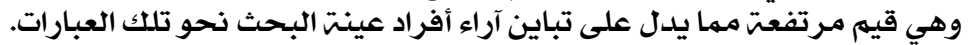

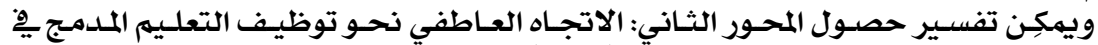

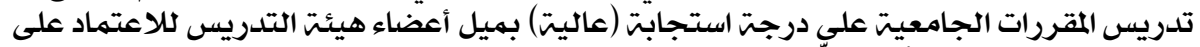

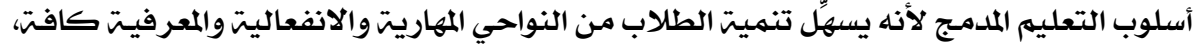
بالإضافت إلى توفيره للوقت والجيم لألهود. 


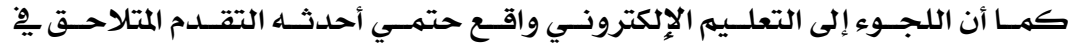

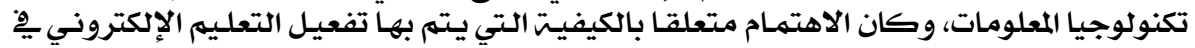

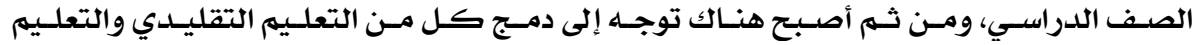

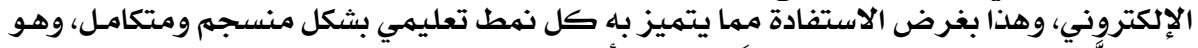

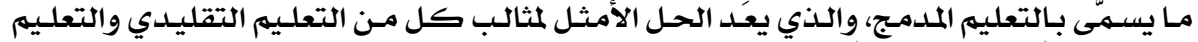

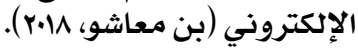

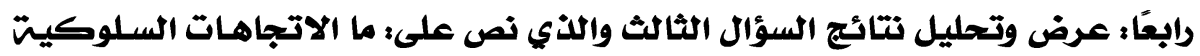

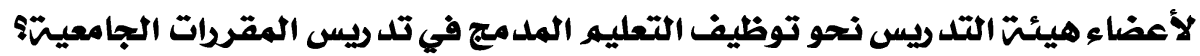

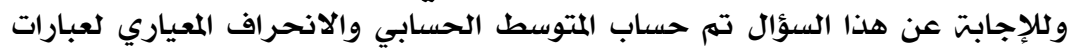

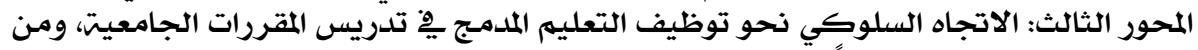

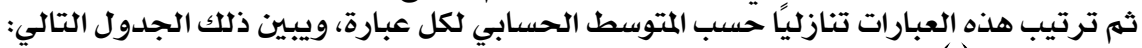

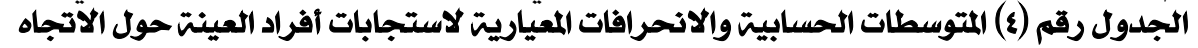

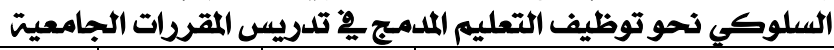

\begin{tabular}{|c|c|c|c|c|c|}
\hline الاستجابت & الترتيب & الانعياري & المتوسطابي & العبارة & \\
\hline عاليت & 1 & 1.351 & 3.68 & 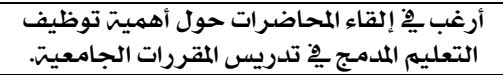 & $r$ \\
\hline عاليت & $r$ & 1.224 & 3.57 & 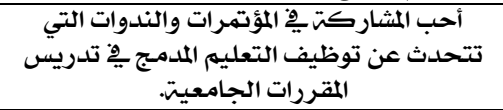 & $Y Y$ \\
\hline عاليت & $r$ & 1.254 & 3.54 & 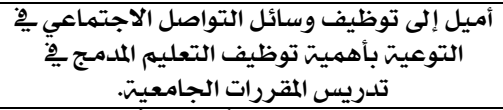 & $r r$ \\
\hline عاليت & 0 & 1.357 & 3.51 & 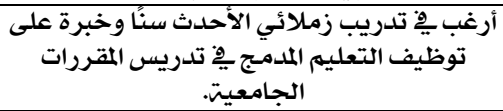 & $Y \xi$ \\
\hline عاليت & 1. & 1.366 & 3.40 & 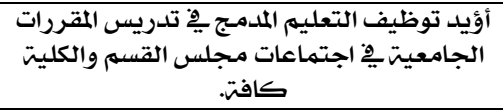 & ro \\
\hline عاليت & 9 & 1.309 & 3.45 & 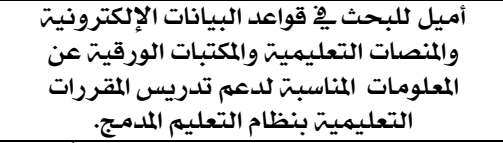 & די \\
\hline عاليت & $\wedge$ & 1.282 & 3.46 & 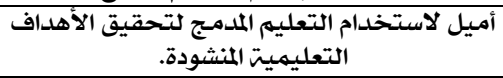 & $r V$ \\
\hline عاليت & $\varepsilon$ & 1.501 & 3.52 & 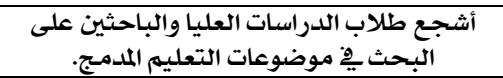 & $Y \Lambda$ \\
\hline عاليت & 1 & 1.434 & 3.51 & 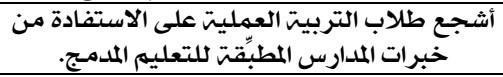 & rq \\
\hline عاليت & $v$ & 1.357 & 3.49 & 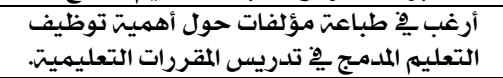 & $r$. \\
\hline \multicolumn{2}{|c|}{ عاليت } & .749 & 3.51 & \multicolumn{2}{|l|}{ المتوسط العام } \\
\hline
\end{tabular}

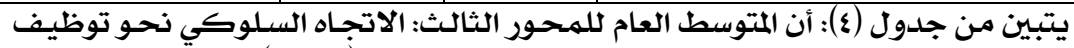

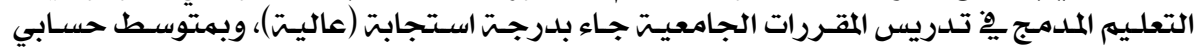

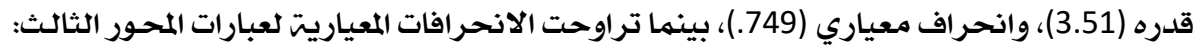

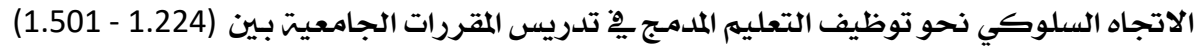

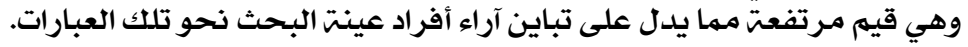




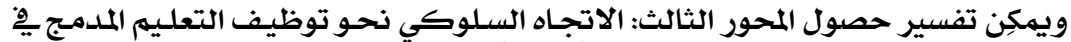

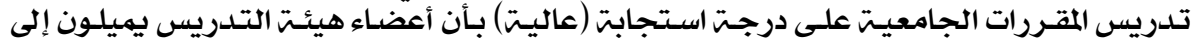

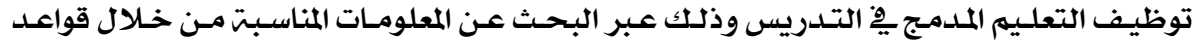

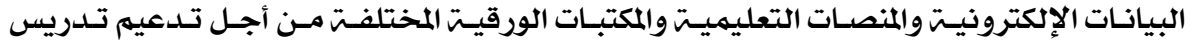

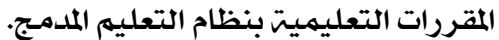

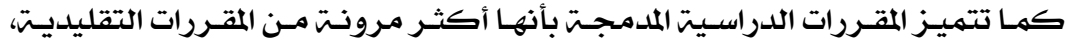

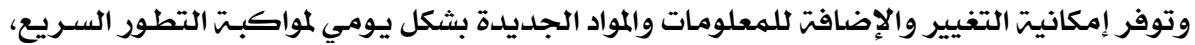

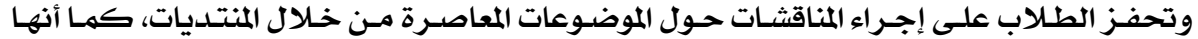

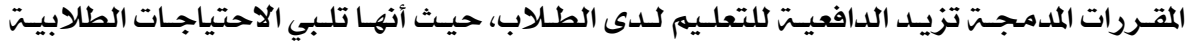
بسهولت (Krasnova\&Popova, 2016,P. 2).

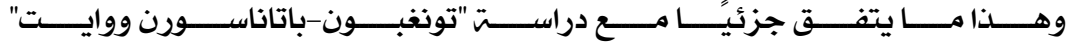

(Tongpoon-Patanasorn \& White, 2020)

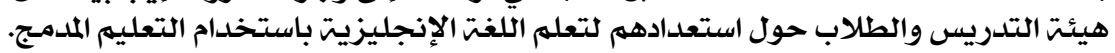
خامسًاء عرض وتحليل نتائج السؤال الرابع والذي نص على: هل توجل فروق ذات دلاتش إحصائيت بين اتجاهات أعضاء هيئن التلدريس ذحو توظّيف التعليم الملمجر في تل ريس المقررات الجامعيت تعزى لمتغيرات البحث (الرتبن الأكاديمينت - النوع -

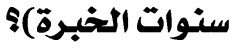
ولإجابت على هذا السؤال تم استخدام اختبار (T-test)، واختبار تحليل التباين الأحادي (One Way Anova)

\section{أ- الفروق الإحصاثيت باختلاف متغير الرتبت الأكاديميت:}

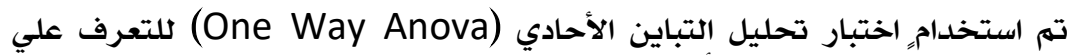

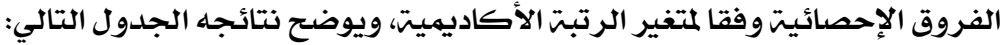

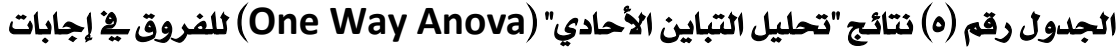

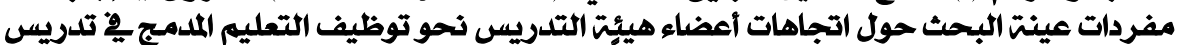

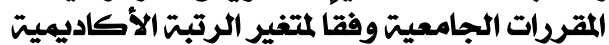

\begin{tabular}{|c|c|c|c|c|c|c|}
\hline |الإحصائيت & قيمتة ف & متوسط المربعات & درجات الحريت & مالمربعات & مصدر التباين & المحاور \\
\hline \multirow{3}{*}{.104} & \multirow{3}{*}{2.105} & 1.134 & 3 & 3.401 & بين المجموعات & \multirow{3}{*}{ 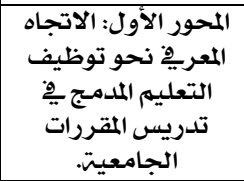 } \\
\hline & & .538 & 109 & 58.691 & داخل المجموعات & \\
\hline & & - & 112 & 62.091 & المجموع & \\
\hline \multirow{3}{*}{.109} & \multirow{3}{*}{2.063} & 1.141 & 3 & 3.423 & بين المجموعات & \multirow{3}{*}{ 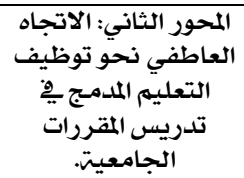 } \\
\hline & & .553 & 109 & 60.298 & داخل المجموعات & \\
\hline & & - & 112 & 63.721 & المجموع & \\
\hline \multirow{3}{*}{.285} & \multirow{3}{*}{1.280} & .712 & 3 & 2.136 & بين المجموعات & \multirow{3}{*}{ 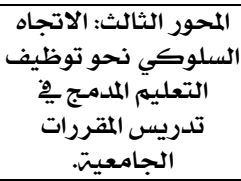 } \\
\hline & & .556 & 109 & 60.634 & داخل المجموعات & \\
\hline & & - & 112 & 62.770 & المجموع & \\
\hline \multirow{3}{*}{.079} & \multirow{3}{*}{2.325} & .873 & 3 & 2.619 & |بين المجموعات | & \multirow{3}{*}{ المتوسط العام } \\
\hline & & .375 & 109 & 40.926 & داخل المجموعات & \\
\hline & & - & 112 & 43.546 & المجموع & \\
\hline
\end{tabular}




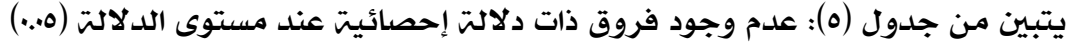

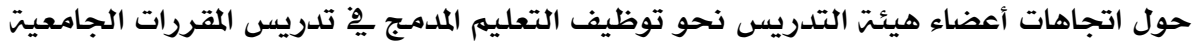

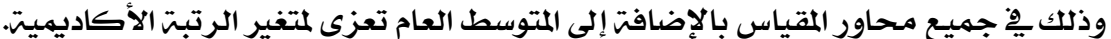

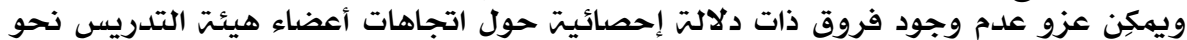

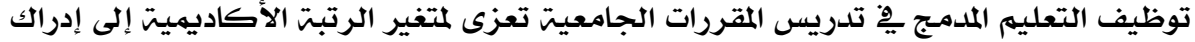

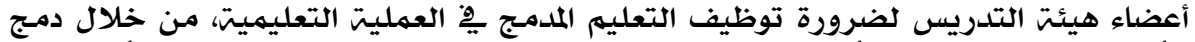

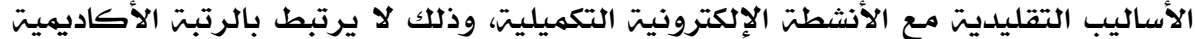

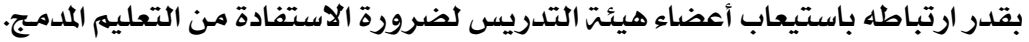

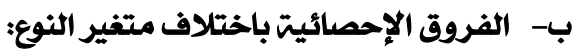

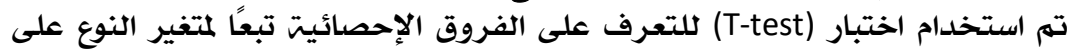

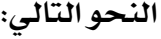

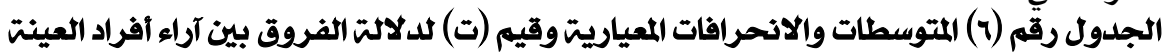

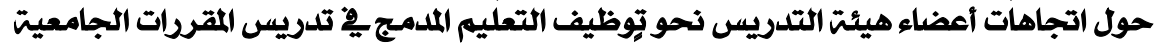

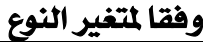

\begin{tabular}{|c|c|c|c|c|c|c|c|c|}
\hline الدلالت & الدلالتي & الحرجيت & المحسوتيت & الالانحرافي & المتوسط & العدد & النوع & المحاور \\
\hline \multirow[b]{2}{*}{ غير } & \multirow[b]{2}{*}{.499 } & \multirow[b]{2}{*}{111} & \multirow[b]{2}{*}{.678- } & .838 & 3.56 & 55 & ذكر & \multirow{2}{*}{ 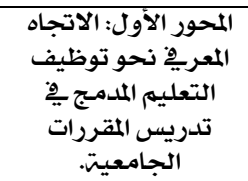 } \\
\hline & & & & .647 & 3.66 & 58 & أنثى & \\
\hline \multirow[b]{2}{*}{ غير } & \multirow[b]{2}{*}{.996} & \multirow[b]{2}{*}{111} & \multirow[b]{2}{*}{.005- } & .766 & 3.55 & 55 & ذكر & \multirow{2}{*}{ 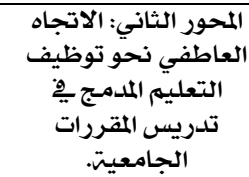 } \\
\hline & & & & .749 & 3.55 & 58 & أنثى & \\
\hline \multirow[b]{2}{*}{ غآل } & \multirow[b]{2}{*}{.836} & \multirow[b]{2}{*}{111} & \multirow[b]{2}{*}{$.208-$} & .712 & 3.50 & 55 & ذكر & \multirow{2}{*}{ 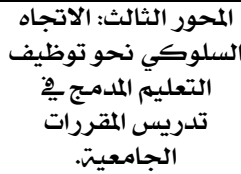 } \\
\hline & & & & . 788 & 3.53 & 58 & أنثى & \\
\hline \multirow{2}{*}{ غير } & \multirow{2}{*}{.724} & \multirow{2}{*}{111} & \multirow{2}{*}{.354- } & .662 & 3.54 & 55 & ذكر & \multirow{2}{*}{ المتوسط العام } \\
\hline & & & & .590 & 3.58 & 58 & أنثى & \\
\hline
\end{tabular}

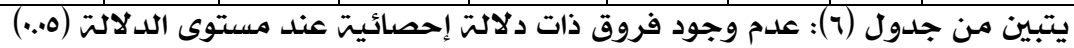

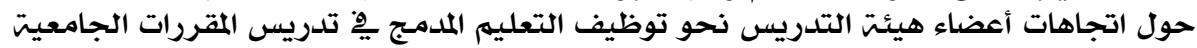

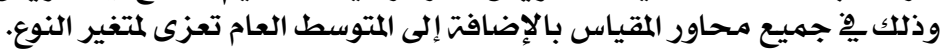

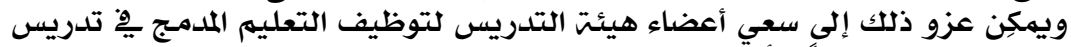

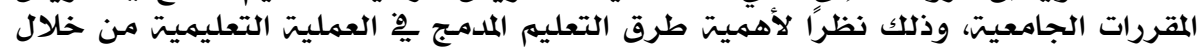

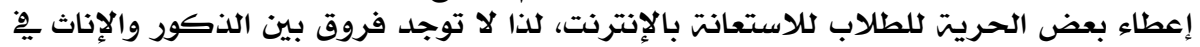

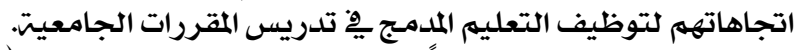

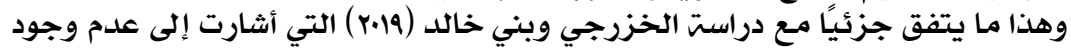

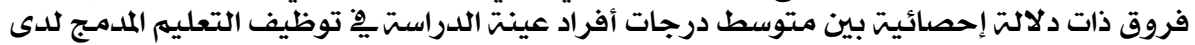

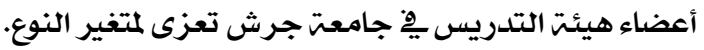




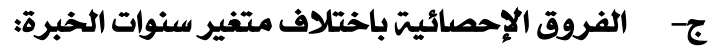

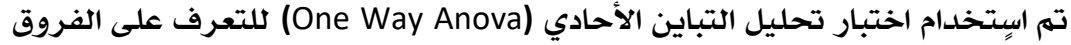

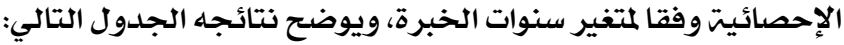

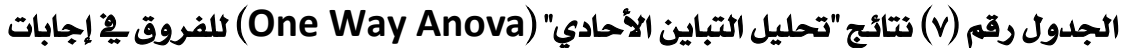

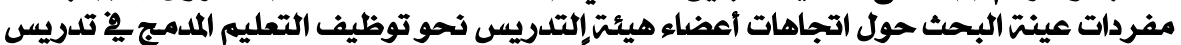

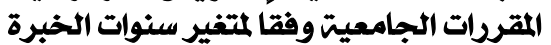

\begin{tabular}{|c|c|c|c|c|c|c|}
\hline الإحصائيت & قيمت ف & متوسطات & درجات الحريت & مجربعات & مصدر التباين & المحاور \\
\hline \multirow{3}{*}{.067} & \multirow{3}{*}{2.772} & 1.489 & 2 & 2.979 & بين المجموعات & \multirow{3}{*}{ 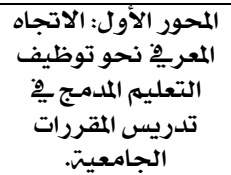 } \\
\hline & & .537 & 110 & 59.112 & داخل المجموعات & \\
\hline & & - & 112 & 62.091 & المجموع & \\
\hline \multirow{3}{*}{.327} & \multirow{3}{*}{1.131} & .642 & 2 & 1.284 & بين المجموعات & \multirow{3}{*}{ 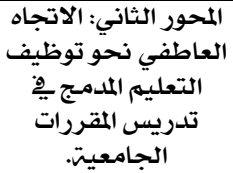 } \\
\hline & & .568 & 110 & 62.438 & داخل المجموعات & \\
\hline & & - & 112 & 63.721 & المجموع & \\
\hline \multirow{3}{*}{.527} & \multirow{3}{*}{.645} & .364 & 2 & .727 & بين المجموعات & \multirow{3}{*}{ 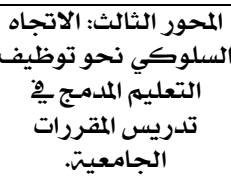 } \\
\hline & & .564 & 110 & 62.043 & داخل المجموعات & \\
\hline & & - & 112 & 62.770 & المجموع & \\
\hline \multirow{3}{*}{.168} & \multirow{3}{*}{1.810} & .694 & 2 & 1.388 & بين المجموعات & \multirow{3}{*}{ المتوسط العام } \\
\hline & & .383 & 110 & 42.158 & داخل المجموعات & \\
\hline & & - & 112 & 43.546 & المجموع & \\
\hline
\end{tabular}

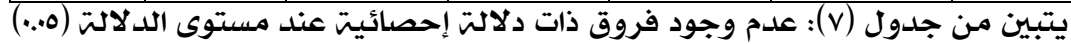

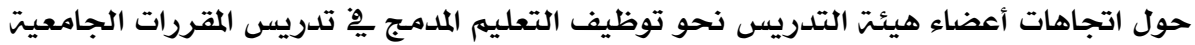

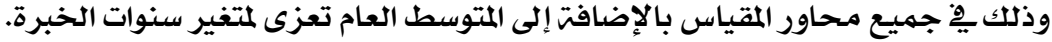

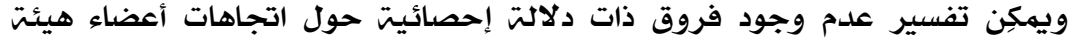

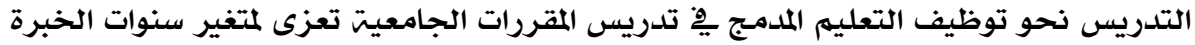

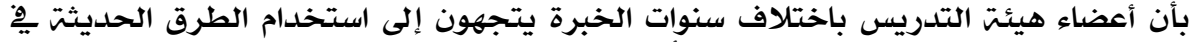

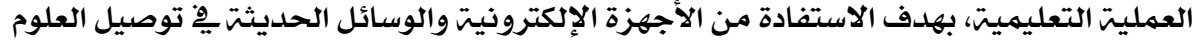

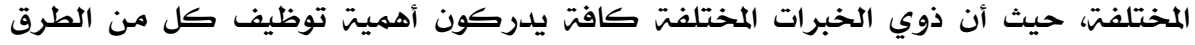

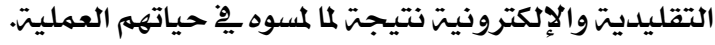

\section{ملخص نتائج البحث}

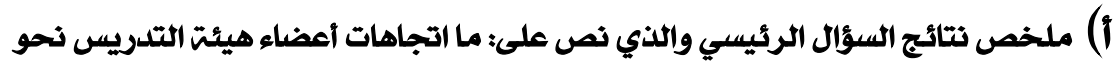

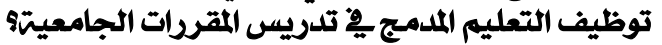

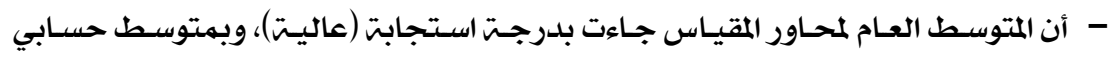

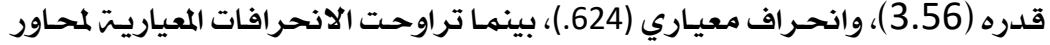

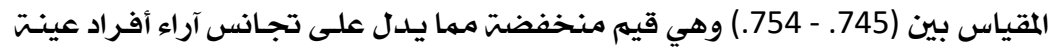
البحث نحو تلك المحاور (المبي 
ب) ملخص نتائج السؤال الأول والذي نص على: ما الاتجاهات المعرفيت لأمضاء هيئت

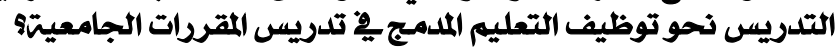

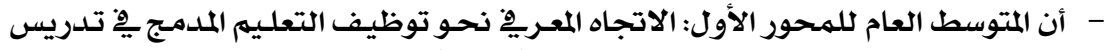

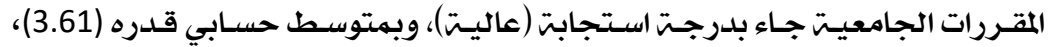

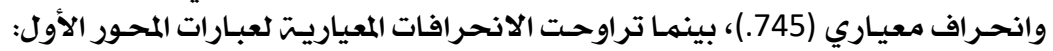

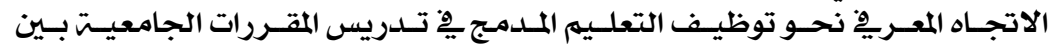

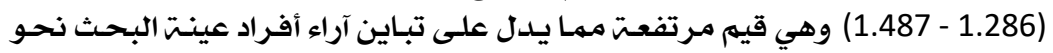
تلك العبارات.

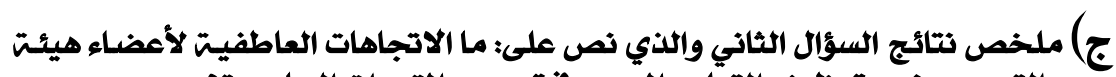

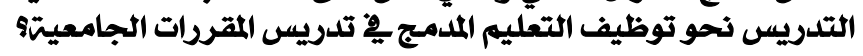

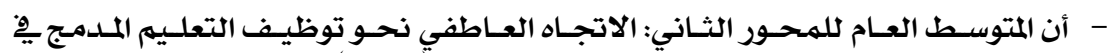

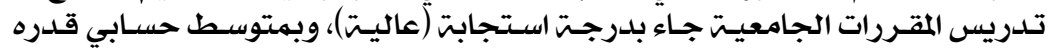

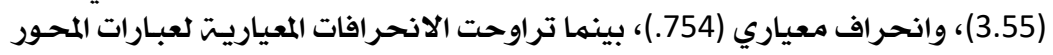

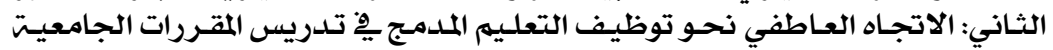

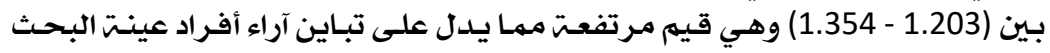
نحو تلك العبارات.

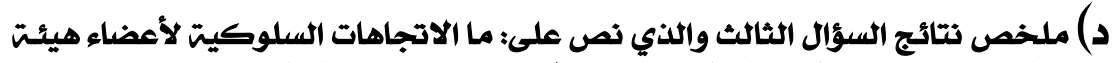

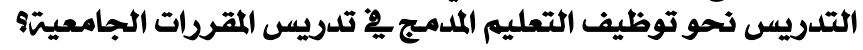

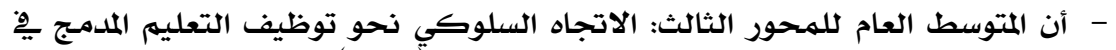

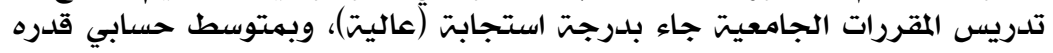

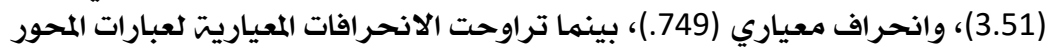

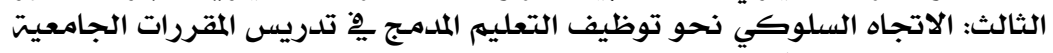

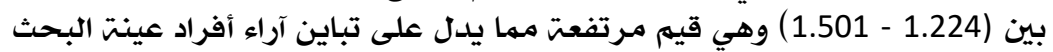
نحو تلك العبارات.

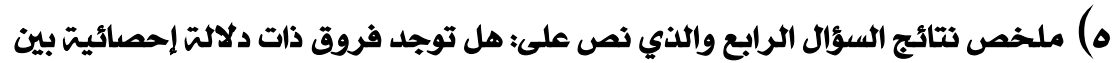

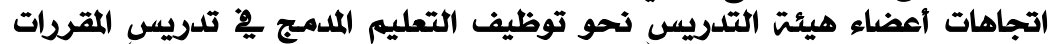

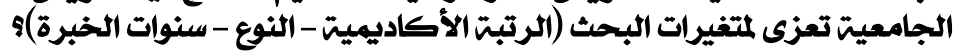

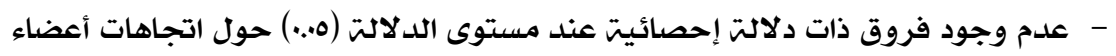

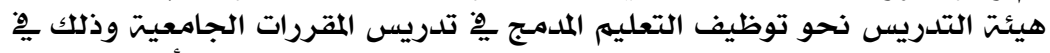

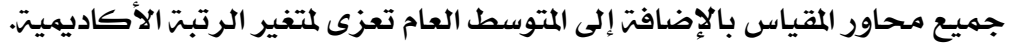

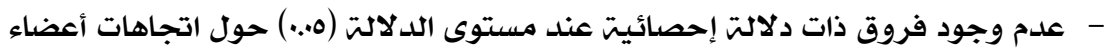

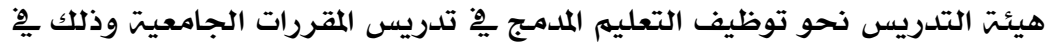

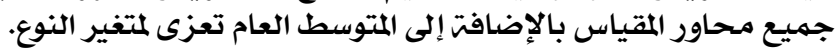

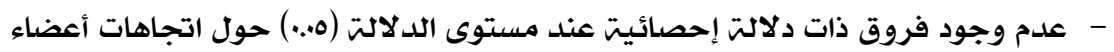

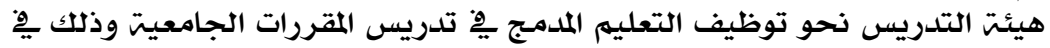

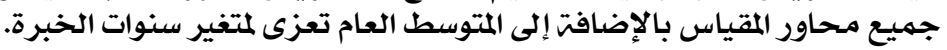




\section{توصيات البحث}

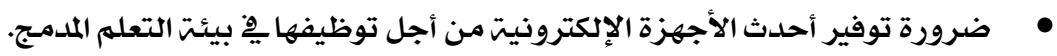

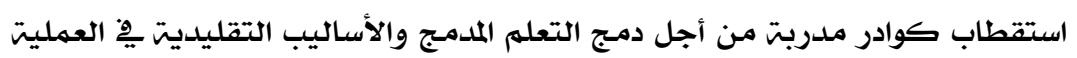

التعليميتة.

عمل ورش تدريبيت من أجل تدريب أعضاء هيئت التدريس على توظيف أساليب تطبيق

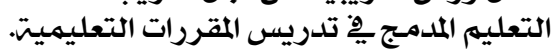

• • •

• الاهتمام بتوفير بنيت تحتيت تعمل على تعزيز عمليت التعلم المدمـج.

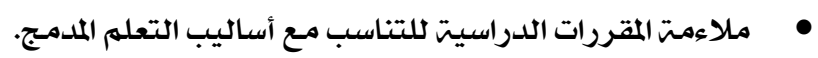

اللد راسات المقترحت ماءمت المقررات

بناء تصور مقترح حول طرق التغلب على الصعوبات التي تواجه أعضاء هيئت التدريس

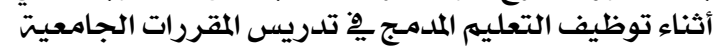




\section{المراجع}

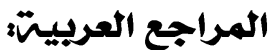

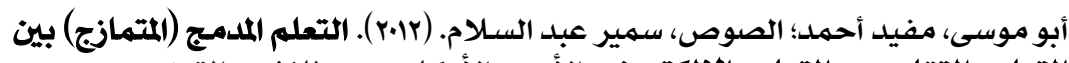

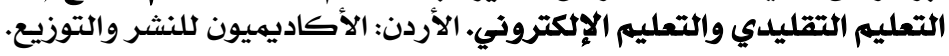

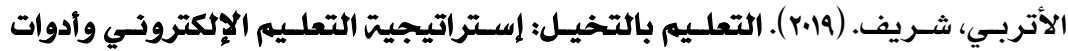

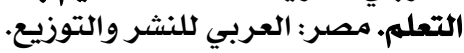

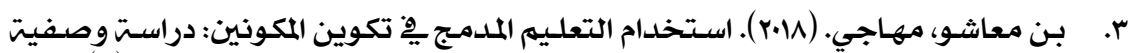

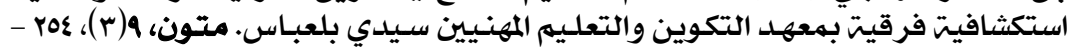
. .rV.

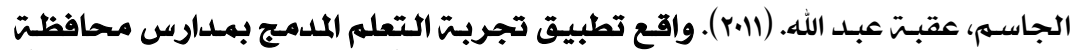

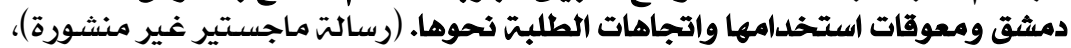

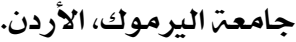

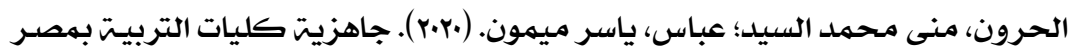

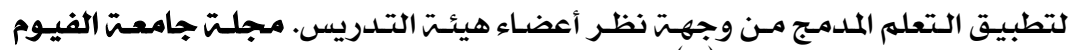

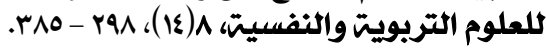

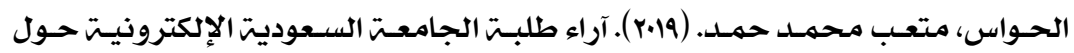

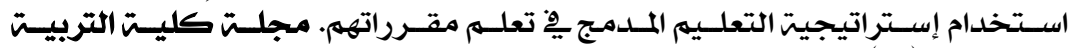

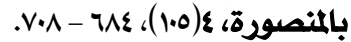

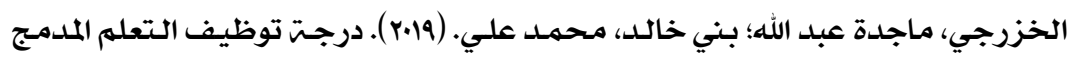

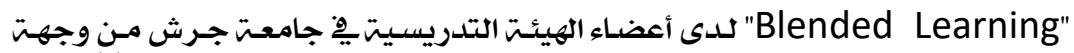

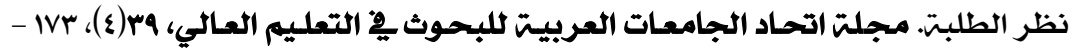
$.1 \mathrm{MN}$

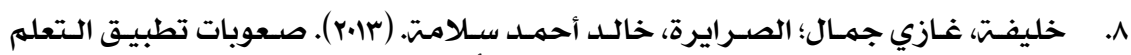

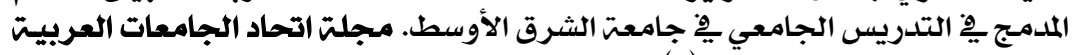

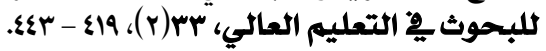

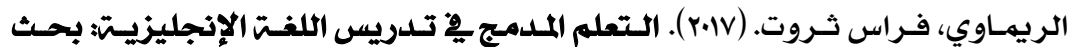

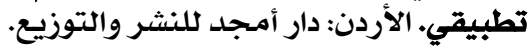

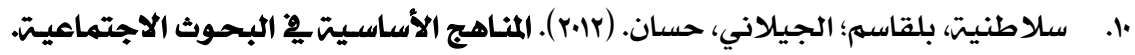
مصر: دار الفجر للنشر والتوزيع.

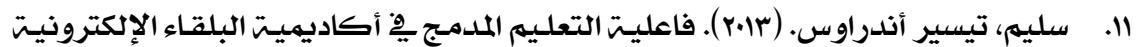

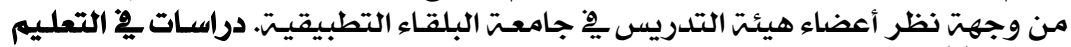

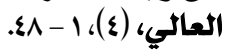

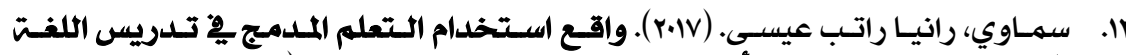

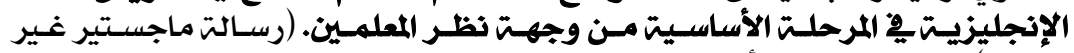
مشورة)، جامعت جرش، الأردان.

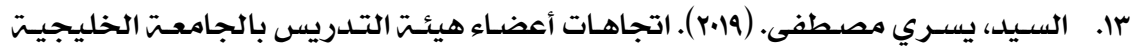

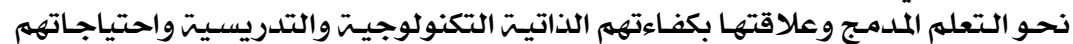

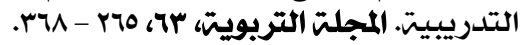




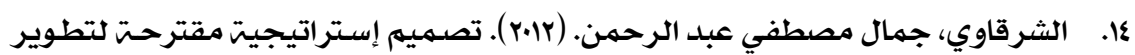

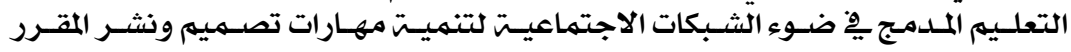

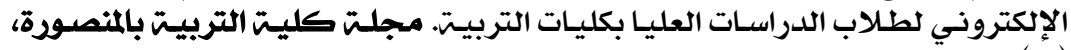
. $70 \varepsilon-0 \varepsilon r_{6}$ ، (1)

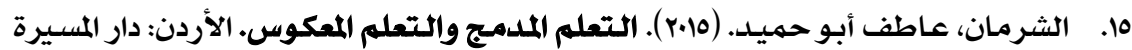
للنشر والتوزيع والطباعتة.

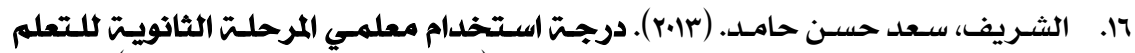

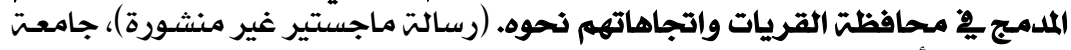
اليرموك، الأردن.

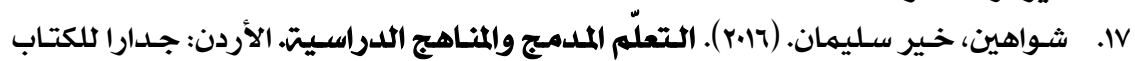

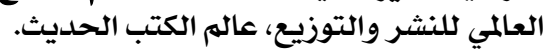

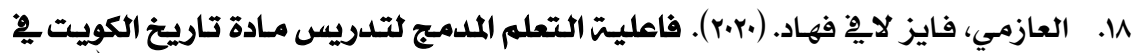

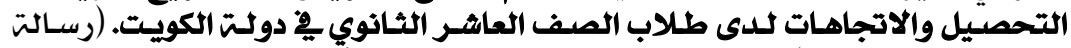

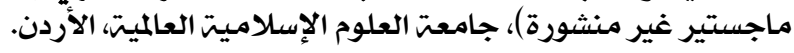

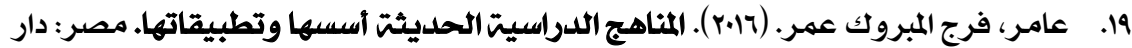

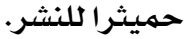

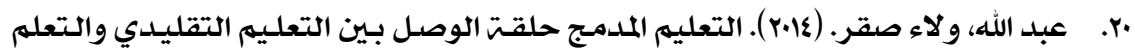

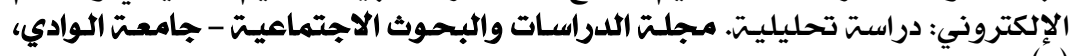
r. - ir (v)

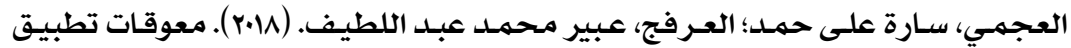

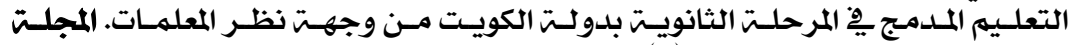

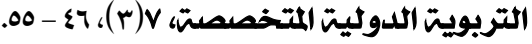

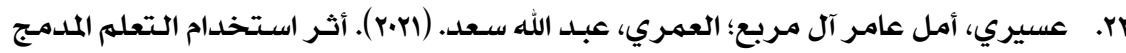

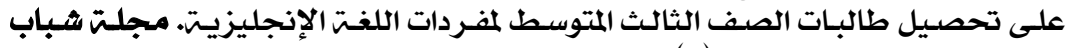

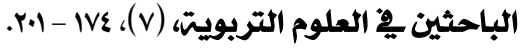

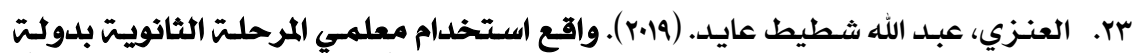

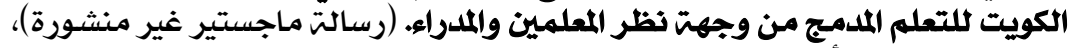
جامعت آل البيت، الأردن.

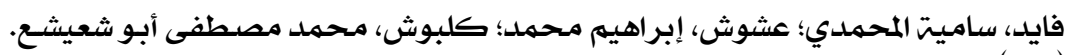

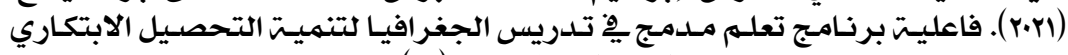

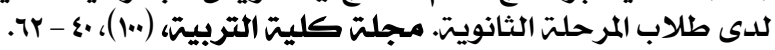

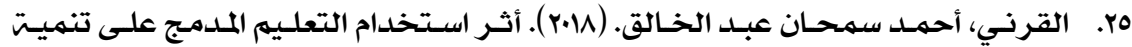

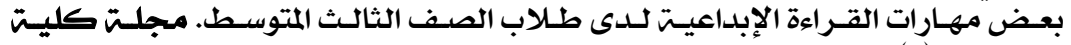

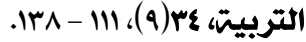

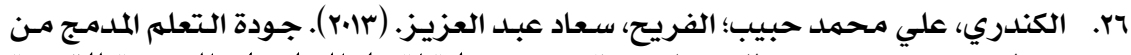

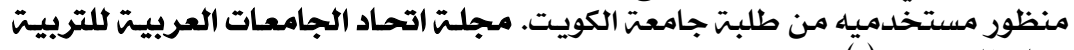

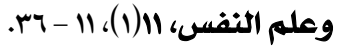

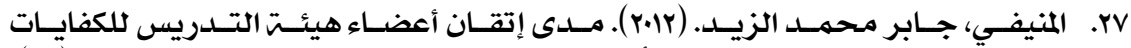

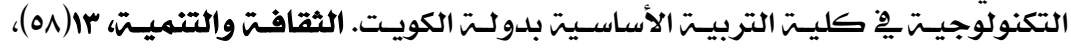
IVY-11T 


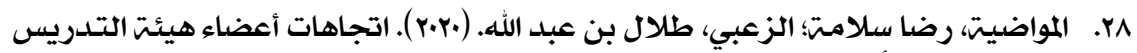

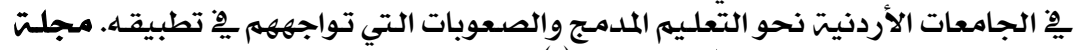

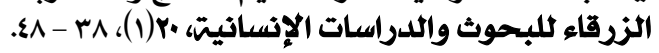

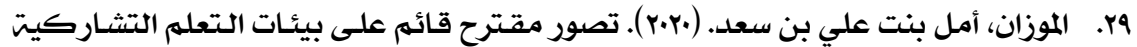

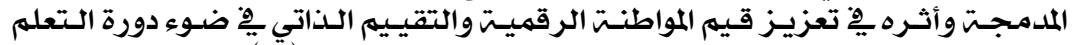

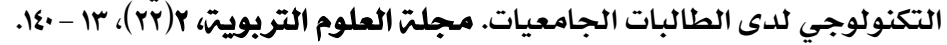

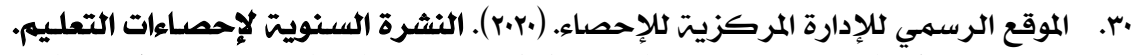

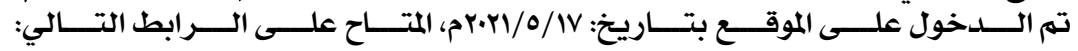
file://C:/Users/DRASA/Downloads/\%D8\%A5\%D8\%AD\%D8\%B5\%D8 \%A7\%D8\%A1\%D8\%A7\%D8\%AA \%D8\%A7\%D9\%84\%D8\%AA\%D8\%B .9\%D9\%84\%D9\%8A\%D9\%85 2019-2020.pdf

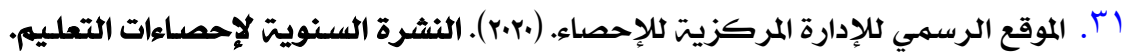

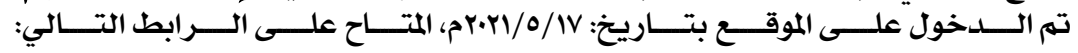
file:///C:/Users/DRASA/Downloads/\%D8\%A5\%D8\%AD\%D8\%B5\%D8 \%A7\%D8\%A1\%D8\%A7\%D8\%AA \%D8\%A7\%D9\%84\%D8\%AA\%D8\%B .9\%D9\%84\%D9\%8A\%D9\%85 2019-2020.pdf

32. Alsalhi, N. R., Eltahir, M. E., \& Al-Qatawneh, S. S. (2019).The effect of blended learning on the achievement of ninth grade students in science and their attitudes towards its use. Heliyon, 5(9), 1-11.

33. Bordoloi, R., Das, P., \& Das, K. (2021). Perception towards online/blended learning at the time of Covid-19 pandemic: an academic analytics in the Indian context. Asian Association of Open Universities Journal, 1-20.

34. Ellis, R. A., Bliuc, A. M., \& Han, F. (2021).Challenges in assessing the nature of effective collaboration in blended university courses. Australasian Journal of Educational Technology, 37(1), 1-14.

35. Hamza-Lup, F. G., \& White, S. (2015). Design and assessment for hybrid courses: Insights and overviews. International Journal on Advances in Life Sciences, 7(3\&4), 122-131.

36. Ilgu, A. K. \& Jahren P.E., C. T. (14-17, June, 2015). Faculty perspectives on benefits and challenges of hybrid learning. 122nd asee annual conference $\&$ exposition, Seattle, WA.

37. Katzin, G. A. (2020). A Phenomenological Study of Teacher Perceptions of Blended Learning: Definition, Adoption, and Professional Development. Doctoral dissertation, Lindenwood University, Missouri.

38. Klimova, B., Simonova, I., \&Poulova, P. (2017). Blended learning in the university English courses: case study. Lecture Notes in Computer Science, $1-13$. 
39. Krasnova, T. I., \&Popova, A. (2016).Exploring the tutor-student interaction in a blended university course.SHS Web of Conferences.28, 1-6.

40. McGee, P., \& Reis, A. (2012). Blended course design: A synthesis of best practices. Journal of Asynchronous Learning Networks, 16(4), 7-22.

41. McHone, C. (2020). Blended Learning Integration: Student Motivation and Autonomy in a Blended Learning Environment. PhD, East Tennessee State University, Tennessee.

42. Mohammed Abdel-hakam, N. (2018). The Effect of Using the Station Rotation Model on Preparatory Students' Writing Performance. Master, Ain Shams University, Cairo.

43. Napier, N. P., Dekhane, S., \& Smith, S. (2011). Transitioning to blended learning: Understanding student and faculty perceptions. Journal of Asynchronous Learning Networks, 15(1), 20-32.

44. Porter, W. W., \& Graham, C. R. (2016). Institutional drivers and barriers to faculty adoption of blended learning in higher education. British Journal of Educational Technology, 47(4), 748-762.

45. Saeed, N. (2020). Teachers' perceptions On The Use Of The Blended Learning. PhD, Houston Baptist University, Texas.

46. Strange, K. Z. (2020). The Impact of Identity: Faculty Identity and Professional Development in Higher Education. Doctoral dissertation, Northern Arizona University, Arizona.

47. Tongpoon-Patanasorn, A., \& White, C. (2020). Teachers' and students' perceptions on blended learning in tertiary English language courses: a match?. Universal Journal of Educational Research 8(6): 2455-2463.

48. Washington, R. (2016). Enabling Change: Faculty and Student Perceptions of Blended Learning. PhD, University Of The Incarnate Word, Texas.

49. Wong, M. (2020). Impact of Blended Learning on Mathematics Achievement. Doctoral dissertation, Lamar University, Beaumont.

50. Zaiter, B. (2020). Attitudes of Faculty Members at the American University of Beirut (AUB) toward Teaching Face-to-Face vs. Online vs. Blended Courses.Doctoral dissertation, Benedictine University, Illinois. 